Portland State University

PDXScholar

Spring 2018

\title{
Evaluating the Effectiveness of Restoration Treatments to Enhance Oregon White Oak Systems within the Klickitat River Watershed
}

Kara Caselas

Portland State University

Follow this and additional works at: https://pdxscholar.library.pdx.edu/mem_gradprojects

Part of the Environmental Studies Commons, and the Forest Management Commons Let us know how access to this document benefits you.

\section{Recommended Citation}

Caselas, Kara, "Evaluating the Effectiveness of Restoration Treatments to Enhance Oregon White Oak Systems within the Klickitat River Watershed" (2018). Master of Environmental Management Project Reports. 31.

https://pdxscholar.library.pdx.edu/mem_gradprojects/31

https://doi.org/10.15760/mem.3

This Project is brought to you for free and open access. It has been accepted for inclusion in Master of Environmental Management Project Reports by an authorized administrator of PDXScholar. Please contact us if we can make this document more accessible: pdxscholar@pdx.edu. 


\section{Evaluating the Effectiveness of Restoration Treatments to Enhance Oregon White Oak Systems within the Klickitat River Watershed}

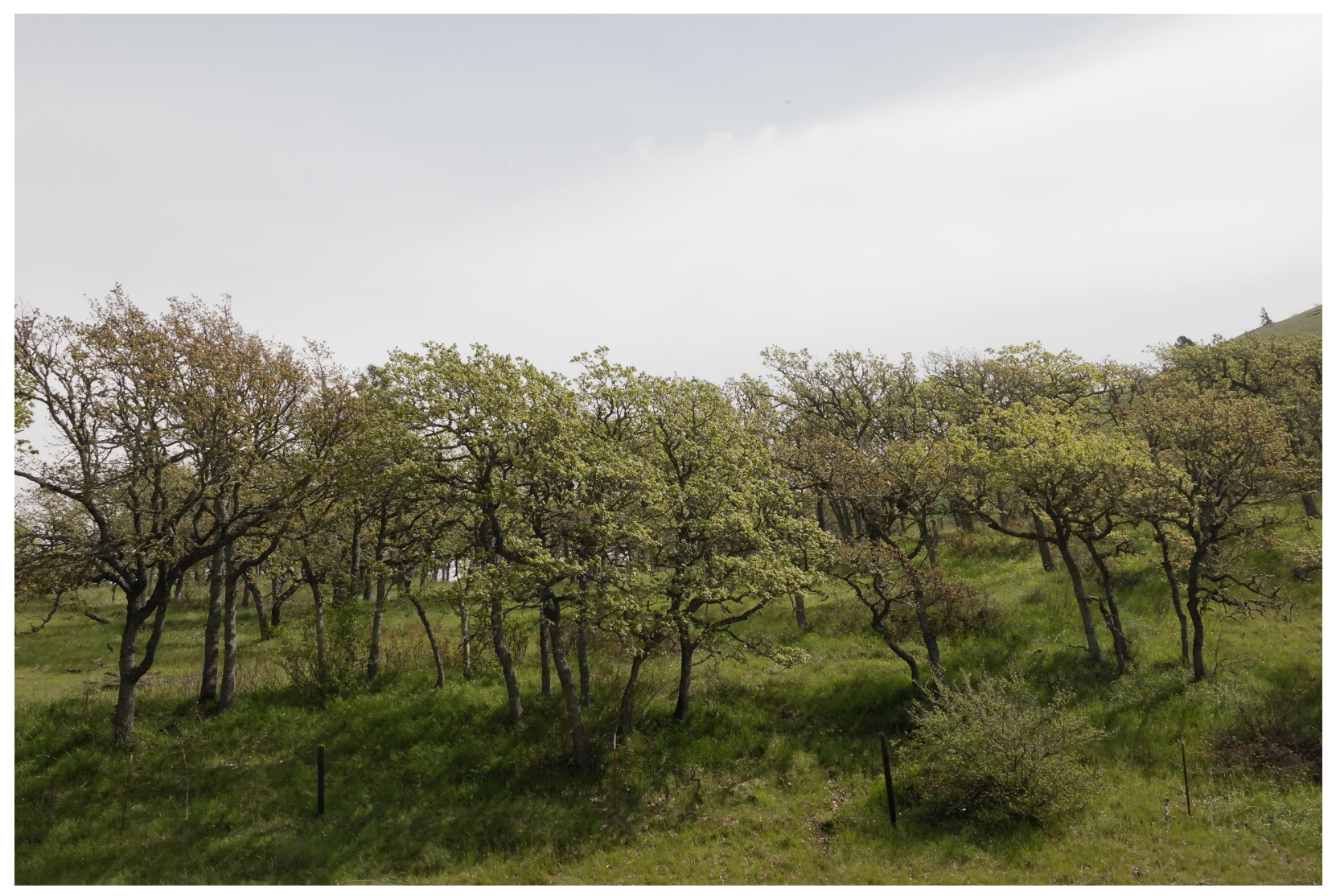

Kara Caselas

Masters of Environmental Management

Portland State University

June 8, 2018 


\section{Acknowledgements}

I am grateful to the following individuals for sharing their expertise and investing their time in this project: Lindsay Cornelius, Columbia Land Trust; Tanner Scrivens, Columbia Land Trust; Dr. Yangdong Pan, Portland State University; Dr. Jennifer Morse, Portland State University; Brian Beaulaurier, Skookum Resource Management; Tim Wise, Skookum Resource Management; Emily Matson, Columbia Land Trust; Nathan Kossnar, Columbia Land Trust; and Michael Young, field assistant.

I also wish to thank my advisor Dr. Jeffrey Gerwing for his guidance in developing and pursuing this project. In particular I am grateful for his investment in my work, his long-range perspective and counsel throughout this project. To my family and friends who encouraged me to pursue my passion, I am forever grateful, and to Chris for his humor and support when I needed it most.

This project was partially funded by the Edward and Olive Bushby Scholarship awarded on 6/15/2017, by the Department of Environmental Science and Management at Portland State University. 
Table of Contents

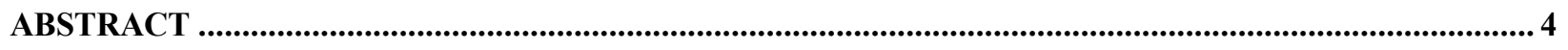

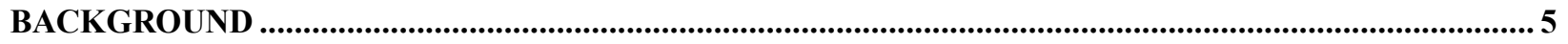

PROJECT LOCATION

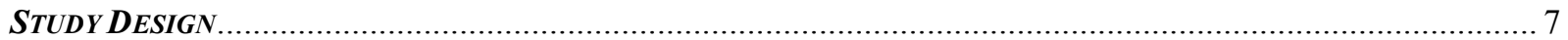

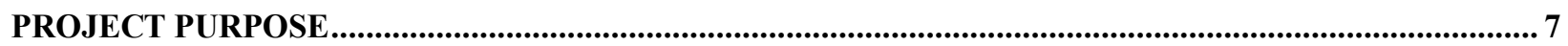

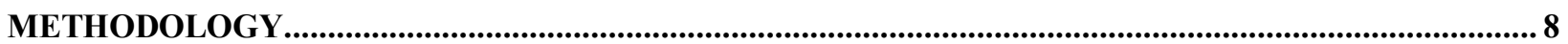

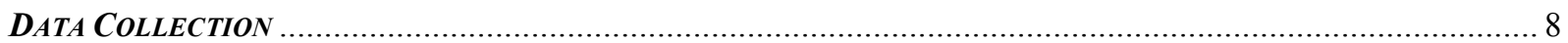

Plot measurements of trees, seedlings, saplings, and stump sprouting ................................................ 8

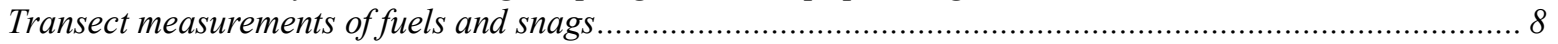

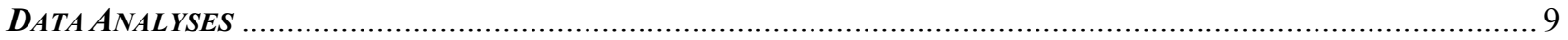

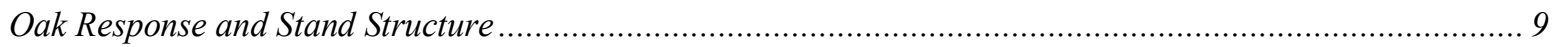

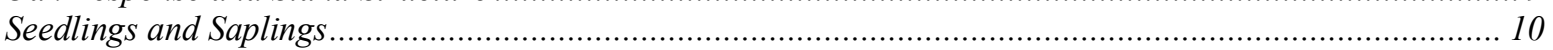

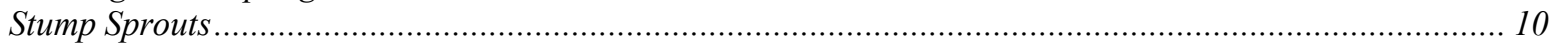

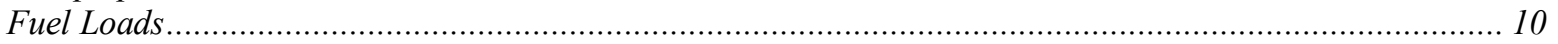

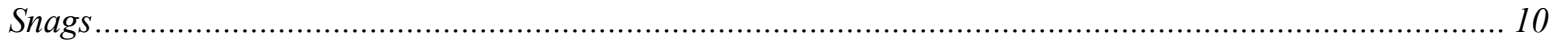

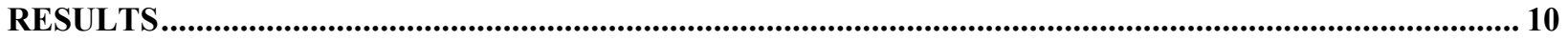

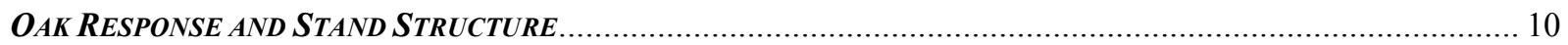

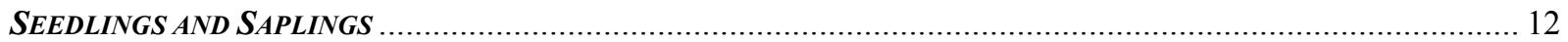

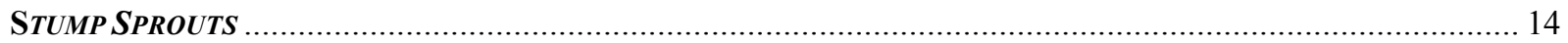

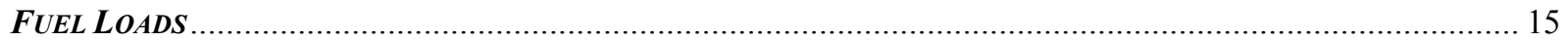

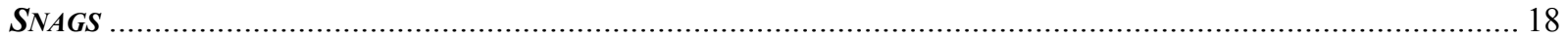

DISCUSSION .................................................................................................................................................... 19

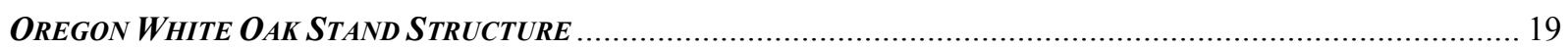

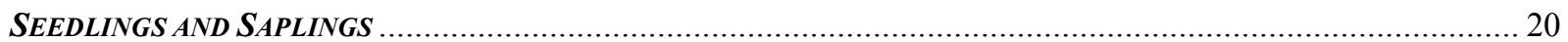

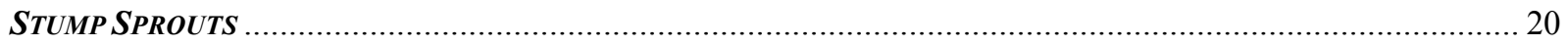

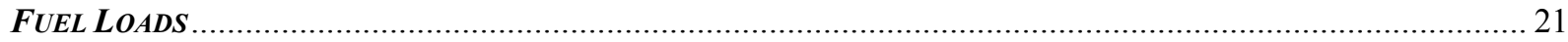

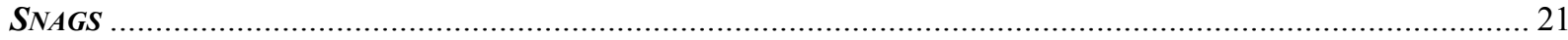

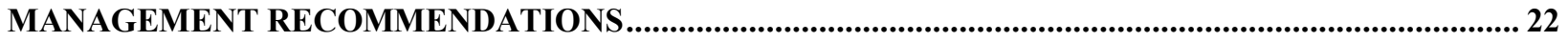

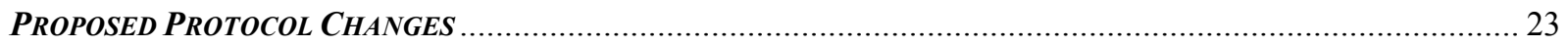

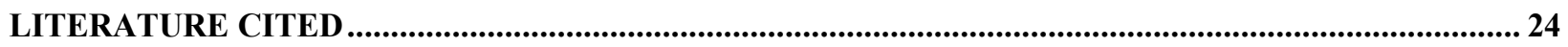

APPENDICES.................................................................................................................................................. 28

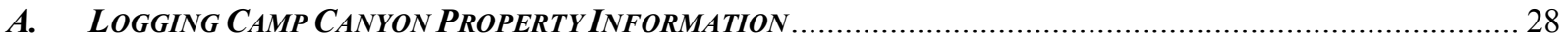

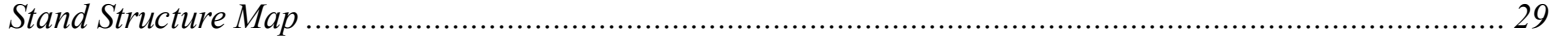

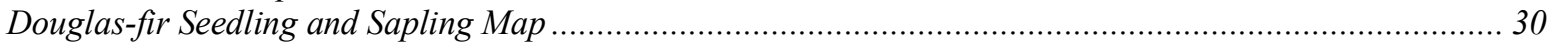

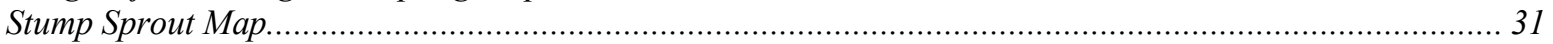

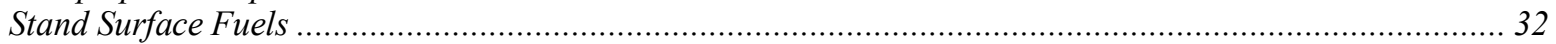

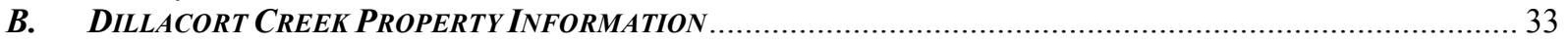

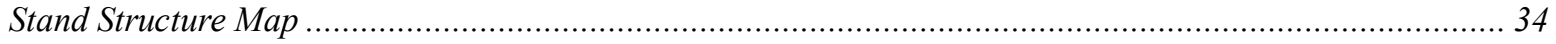

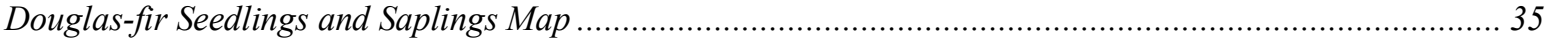

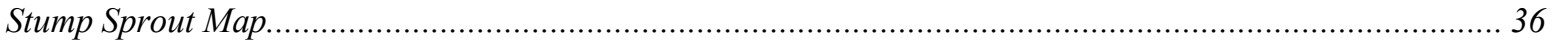

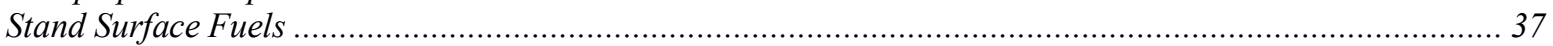




\begin{abstract}
Oregon white oak (Quercus garryanna) and associated plant communities provide key habitat to a number of plant and animal species, including Washington state listed threatened populations of Western grey squirrel. Over the past 150 years, human actions such as logging, fire suppression and grazing have altered stand structure and species composition of oak systems, reducing the extent and quality of historic Oregon white oak habitat. Oregon white oak and associated habitats are common in Klickitat County, which has one of the largest remaining acreages of Oregon white oak systems in the state of Washington. While most oak systems in the Pacific Northwest are found on private lands, Klickitat County contains a significant percentage of oak resources under public ownership, which provides unparalleled opportunities for landscape level management of oak systems. One management strategy public agencies and private landowners have been using to restore oak woodlands and savannas is oak release, in which conifers are removed or doghair oak stands are thinned to enhance stand conditions, improve wildlife features, and reduce the risk of habitat destroying fire. I examined the response of Oregon white oak trees thirteen years post-treatment, evaluating oak growth, seedling and cut stump responses, fuel load accumulation and changes in snag abundance, and compared these findings to untreated areas. Oak diameter, height and live-crown ratio were not significantly influenced by treatment; however, released stands displayed greater increases in tree diameters than were observed in control groups. Seedling and sapling recruitment of released stands were both significantly different from control stands. Logistic regression showed that percent canopy cover was a significant factor in determining the probability of oak stump sprout. Fuel treatments during release successfully reduced the amount of surface fuels across the study site, however overall fuel height increased between the study years. Lastly, snag abundance declined between the study years. I recommended management strategies for future implementation and protocol modifications for subsequent monitoring to help evaluate long-term release impacts.
\end{abstract}




\section{Background}

Oregon white oak (Quercus garryana) is valued in the Pacific Northwest for its contributions to biodiversity and for its cultural significance (Chappell and Crawford 1997, Carey and Wilson 2001). It is capable of growing on a wide variety of sites; however, it is relatively slow-growing and on moister sites it is often outcompeted by other tree species such as Douglas-fir (Pseudotsuga menziessi). Historically, the regular occurrence of fire favored Oregon white oak over less fire-tolerant tree species. West of the Cascade Range, the regular burning of Oregon white oak woodlands by indigenous peoples was a major factor that maintained oak systems (Dunwiddie and Bakker 2011). Historical fire frequencies on the eastside were generally lower, and while woodlands may have been burned periodically by indigenous peoples, ignition through lighting strikes was much more common (Devine et al. 2013). Within both regions, the ranges of oak woodland and savannas have diminished significantly since European settlement due to land conversion for agriculture, development, and the cessation of regular burning. These ecosystems have been reduced to $<10 \%$ of their original extent, with only $<5 \%$ of the remaining habitat in a natural condition. In all of these areas, the surviving remnants tend to be small and highly fragmented (Lea 2006; Crawford and Hall 1997; Chappell et al 2001; Christy and Alverson 2011).

The general patterns of forest succession in oak systems are well documented (Agee 1993). In the absence of fire, successional pathways and the composition and structure of eastside oak stands shift, with increasing number of Oregon white oak filling in open savannas. Where oaks grow more densely, less fire tolerant but faster growing species, such as Douglas-fir and Ponderosa pine (Pinus ponderosa) invade the area. During this period of encroachment, stand structure transitions from a more open, single-storied oak canopy to a relatively dense conifer overstory with an oak midstory. This suppression of oaks results in crown dieback and eventual mortality of the shade-intolerant oak (Stein 1990). Additionally, as the canopy closes native grasses and forbs important to the historic biodiversity of oak systems begin to decline, and the understory shifts towards more herbaceous species commonly associated with dense forests (Ulrich 2010; Crawford and Hall 1997, Thysell and Carey 2001, Foster and Shaff 2003). Conservation and preservation of stands that are still structurally and functionally intact, and restoration of degraded stands, are needed to ensure the longevity of these habitats and the species that rely on it.

Managers have recognized that Oregon white oak communities in many places are threatened and management intervention is necessary to maintain or restore them. Considerable attention has been focused on natural disturbance processes as a guide for forest management. Concepts such as the historic range of variability (Landres et al. 1999) and coarse filter conservation strategies (Hunter 1990, Haufler et al. 1996) suggest that successful management of ecosystems may best be achieved by mimicking natural disturbance patterns and processes. Recently, researchers and land managers have begun to address the issue restoring oak savanna or woodland structure by "releasing" relic oaks from encroaching competition. Removing encroaching fir and reducing overall stand density can enhance stand conditions by increasing light and nutrient sources for remaining trees and is often a necessity when restoring oak woodlands to their historical structure.

In the past two decades the conservation, management and research of Oregon white oak and prairie ecosystems has progressed rapidly west of the Cascade Range in the Willamette Valley - 
Puget Trough - Georgia Basin ecoregion of Oregon, Washington, and British Columbia (Dunwiddie and Bakker 2011). However, Oregon white oak systems east of the Cascade Range crest and in the Columbia River Gorge has so far received less attention, particularly from researchers (Devine and Harrington 2013). Eastside Oregon white oak can be found in dense, pure stands, in open woodlands and savannas, and as a component of mixed oak-conifer stands (Larsen and Morgan 1998). On xeric eastside sites, ponderosa pine is Oregon white oak's most frequent conifer associate, although where soil moisture is greater, Douglas-fir becomes increasingly common (Devine et al. 2013). Much of the historical eastside Oregon white oak savanna and woodland habitat has been lost, and the combined effects of logging, fire suppression, grazing and development threaten significant portions of the remaining extent. In many eastside oak systems, stand structure has shifted from large, widely spaced trees, to denser stands of smaller trees. Few legacy trees remain in the area, but these remaining trees are strongly desired by land managers, as they offer larger cavities of wildlife use, have deeper furrowed bark suitable for lichens and mosses, and are typically very fire resistant (Devine et al. 2103). In 2003 Columbia Land Trust partnered with the Eugene District of the Bureau of Land Management (BLM), the Forest Restoration Partnership and the Yakama Nation to address threats to eastside oak systems by restoring approximately 100 acres of Oregon white oak woodlands in Klickitat County, Washington.

\section{Project Location}

Klickitat County contains a mosaic of beautiful canyonlands dotted with oak woodlands and pines, basalt cliffs, and talus slopes. The Klickitat River flows through the county and represents the band of transitional habitat between the crest of the Cascade Mountains and the dry shrub steppe of eastern Washington. Conditions in the watershed support the development of one of the largest contiguous populations of Oregon white oak woodlands, and support one of the three remaining populations of western grey squirrel in the state. While most oak systems in the Pacific Northwest is found on private lands, Klickitat County contains a significant percentage of oak resources under public ownership, which provides unparalleled opportunities for landscape-level management of these communities in the east side of the Cascades.

Project lands included two properties owned by Columbia Land Trust: Dillacort Creek (580 acres) located between river mile 5 and 6 along the Klickitat River, and Logging Camp Canyon (300 acres) located near river mile 9.5 of the Klickitat River (Figure 1). Stand composition varies somewhat across the two sites, but both sites are predominantly dry oak systems with more limited areas of conifer co-dominant or conifer dominated mesic oak systems. Legacy oaks on the properties suggest the growth potential of oaks throughout the sites and in some cases the stand structure allowed for more open grown, larger diameter oaks.

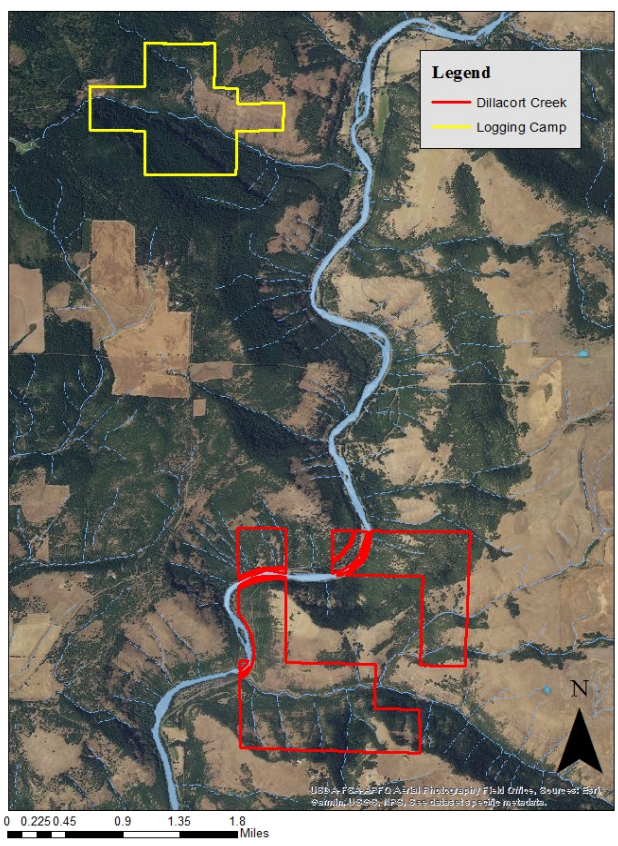

Figure 1: Map of research sites 


\section{Study Design}

In 2003 Columbia Land Trust initiated a resource baseline assessment and inventory which included forest stand condition assessment, understory composition, wildlife features (snags) and fuel load assessments. A permanent inventory plot system was established during the baseline sampling using stratified plot layout totaling 180 plots. Plots were installed in delineated stand polygons with sample intensity based on a range of factors including vegetation heterogeneity, polygon size, and perceived need for restorative treatments. Plot density varied between stand polygons but stands typically had a minimum of 7 plots/stand; with smaller stands having a higher sample intensity. Once baseline inventories were complete management prescriptions were initiated to enhance Oregon white oak forest structure and wildlife habitat, and to reduce the potential adverse impacts resulting from catastrophic fire. To accomplish this, vegetation treatments primarily focused on reducing stand density to achieve the following objectives:

- Improve both mast production and wildlife cavity resources in oaks;

- Reduce the risk of high severity/intensity fire and subsequent loss of oak systems, and allow reintroduction of historic fire regimes;

- Increase downed wood levels of larger diameter boles, while aggregating coarse wood and keeping at levels that do not contribute to crown fire behavior; and,

- Balance maintenance and restoration of habitat conditions for Western gray squirrels, with fire regime objectives mentioned above.

These target objectives were informed through westside oak savanna and woodland restoration projects and were intentionally broad in scope, in order to facilitate an adaptive management approach as eastside oak knowledge and understanding of these systems increases. Treatments were implemented on approximately 100 acres of forested woodlands at Logging Camp Canyon and Dillacort Creek in a mosaic pattern based on site-specific conditions, including buffers around sensitive resources like streams and documented nests of sensitive species. Manual removal, including cutting and pruning of trees with chainsaws and other non-mechanized tools, occurred on steeper slopes or where sensitive environmental conditions occurred. On more level slopes and near adequate existing access routes, rubber tracked skid-steer equipment was used.

\section{Project Purpose}

The purpose of this project was to evaluate the effectiveness of implemented management strategies by comparing data from pre-treatment conditions to new measurements from posttreatment conditions. I assessed five aspects of forest conditions; stand structure, wildlife features, seedling/sapling recruitment, stump sprouting, and fuel loads by evaluating the following questions:

1. How did treatments impact oak growth, canopy structure and regeneration?

2. Are there variables that can determine the predictability of stump sprouting posttreatment and do these variables differ for stumps in clumps?

3. How did the treatments affect fuel loads?

4. How did the treatments affect the abundance and quality of habitat features, such as snags and coarse woody debris? 


\section{Methodology}

\section{Data Collection}

Data collection occurred from June to October of 2017. Unless specified below, the protocol established in the 2003 baseline surveys was the same protocol used in the 2017 data collection.

Plot measurements of trees, seedlings, saplings, and stump sprouting

Sampling plots were located utilizing GPS locations and rebar and plot reference tags that provided directional measurements for plot centers during the original 2003 survey. When plot markers were missing, or unable to be located, plot centers were estimated either through GPS data or reference tree positions. For each delineated stand polygon, a basal area factor (BAF) was determined that would capture 5 to 8 trees per plot within the select stand polygon and the following data recorded for all in the sampling radius: species, diameter at breast height (DBH), occurrence of disease, nests or cavities, and epicormic scores ( $1=$ not branching epicormically, 2 $=$ not obvious or abundant - very sparse; $3=$ locally abundant - isolated to one or a few locations on the bole; 4 = obvious and abundant). Epicormic branches are shoots arising spontaneously from adventitious or dormant buds on stems or branches of woody plants, often following exposure to increased light levels or following disturbance (Helms 1998). For the first and third tree in each plot, height and height to base of live crown were recorded.

Seedling and sapling recruitment was evaluated using a fixed 16.7-foot radius from plot center. Seedlings and saplings found within the designated radius were recorded by species and size class. Saplings were considered to be understory tree greater than 12-inches in height and fell within three DBH ranges: < 1", 1-3", and 3-5" dbh. Trees that forked below 3-inches were considered to be two separate trees. Seedlings were defined as any tree species less than 12inches in height. Counts for plots with dense carpets of seedlings were derived by counting the number of seedlings in a square foot, and approximating coverage by the number of square feet.

Stump response to release treatments was evaluated at odd plot numbers at a fixed radius of 26.3 feet from plot center. For each stump within the radius, sprouting presence or absence was documented. Where present the following information was collected for each sprouting stump: aspect, slope, stump height and diameter, canopy cover $(0-15 \%, 15-30 \%, 30-60 \%, 60-75 \%, 75-$ $100 \%$ ), surrounding vegetation competition percent cover within a 1.5 -foot radius around the stump, and signs of browse. Each stump was also assigned a vigor score of low (0-4 sprouts), medium (5-9 sprouts) or high (10+ sprouts). Average and maximum sprout height were also documented. Additionally, if stumps were part of a clump during release, meaning there was more than one stem within a 3 -foot diameter from the stump, additional variables were measured. For each stump within a clump the number of live stems remaining after release, the number of stumps, and stump sprout response was recorded.

\section{Transect measurements of fuels and snags}

Fuel and coarse woody debris data was collected using a United States Forest Service (USFS) inventory protocol (Brown 1974). From each plot center and heading north a transect tape was laid out to a distance of 60 -feet. Counts of the number of particles that intersected the transect plane were recorded by the following size classes: 
- 1-hour fuels: 0 to 0.24 -inch diameter

- 10-hour fuels: 0.25 to 1 -inch diameter

- 100-hour fuels: 1 to 3-inch diameter

- 1000-hour fuels: exceed 3-inches diameter

Particles qualifying for tally included downed, dead woody material which is defined as material that has fallen to the ground or was severed from its original source. Material lying in the litter layer and above were counted. If the transect plane intersected a curved piece of material more than once, each intersection was tallied. For 1- and 10-hour fuels, counts were recorded along the transect for a horizontal distance of 6-feet. For 100-hour fuels, counts along the transect were recorded for a horizontal distance of 15-feet. Each 1000-hour fuel were recorded along the entire transect length. For 1000-hour fuels, diameter soundness of the wood were also recorded. For rotten logs that were falling apart the diameter was estimated. Lastly, two recordings of fuel height and duff depth were measured at the 6- and 15-foot horizontal position along the transect. Fuel heights included fuel that crossed the transect plane in the air.

A 50-foot wide transect line in the direction of travel between plot locations was used to collect snag data. A snag was defined as any dead tree free-standing between 45 degrees to vertical, with a DBH greater than 6-inches and height taller than 10-feet. When snags were observed, GPS location, species, DBH, height and cavity presence were recorded. Lastly, a decay class score was assigned: 1) Dead. All limbs present, pointed top, 100\% bark intact, height intact; 2) Few limbs remain, top may be broken, some bark and height loss; 3) Limb stubs only, broken bole, bark and sapwood sloughing, broken top; 4) Few stubs remain, bole broken/rotten, 50\% bark and sapwood sloughed; 5) No stubs remain, broken and rotten bole $20 \%$ bark or less, sapwood gone.

\section{Data Analyses}

Although all 180 plots were revisited in 2017, data gaps emerged due to an error in the data collection software. To account for this missing data, and create comparable datasets, only plots with complete data for both years were included in the study area analysis. The software also generated duplicate entries for several plot locations, which were removed prior to analysis. Additionally, the dataset was assessed for outliers. For both fuels and seedling data outliers were observed. Upon further analysis, these outliers were determined to be a data entry errors, due to their being many orders of magnitude larger than the other measurements for that variable. These outliers were removed prior to analysis as the values could not be corrected. All other datasets did not have outliers of concern.

\section{Oak Response and Stand Structure}

Stand data for both years was separated into two datasets, one containing all tree species observed between years and one containing only Oregon white oak information. Live-crown ratios were generated using crown depth to tree height information. In 2003 height and crown depth were measure for all trees. In 2017, only the first and third trees in each plot were measured for height and crown depth. Only the height and crown depth data from the first and third trees in 2003 was used in the analysis to match protocols used in 2017. All variable attributes were converted to plot arithmetic means in order to create one observation per plot. 
To examine patterns in white oak response to release treatments, a Before-After Control-Impact (BACI) design model was used in R Studio (version 1.1.447). In this design, measurements are taken at the treatment and control sites both before and after the treatments occur. BACI designs are preferred over a simpler Before-After comparison, as a change in the response may occur independently of the treatment due to temporal effects. BACI design testing accounts for the potential change in the response variables occurring independently from the treatment impact due to environmental factors not included in the analysis (Schwarz 2014). This design allows treatment impacts to be distinguished from background time effects shared by all sites, as well as background differences between treatment and control sites, through the evaluation of period $\mathrm{x}$ treatment interaction effects (Popescu et al. 2012). In essence, this design controls for spatial differences between treatment and control sites such that they do not have to be identical.

\section{Seedlings and Saplings}

Analysis of seedling and saplings was performed utilizing BACI design testing to evaluate differences in the number of seedlings and tree size classes between study years and treatment areas.

\section{Stump Sprouts}

The data for evaluating stump sprout response included both categorical and numerical data. Prior to analysis, categorical variables canopy closure and slope were assigned codes used as placeholders in analysis testing. Logistic regression was used to analyze the relationship between variables and the probability of sprouting. Logistic regression is a statistical method for developing models with a dichotomous response variable (i.e. sprouting success or failure) (Sands and Abrams 2009). Additionally, a linear regression model was used to determine if significant differences occurred in the number of sprouts between stump height and diameter.

\section{Fuel Loads}

Plot information was grouped by stand delineation and converted into tons per acre for each fuel size class utilizing Forest Service's protocol (Brown 1974). Plot fuel height and duff depth were averaged to create stand totals. To examine differences between fuel classes, height and duff depths a BACI design model was performed.

\section{Snags}

In 2003, snags less than 10-feet tall and smaller than 6-inches DBH were recorded. Snags recorded in 2003 that did not meet the criteria established in 2017 were excluded from the analysis. A comparison of total number of snags, species composition, DBH, and decay class was performed to evaluate how wildlife feature abundance and quality changes over time.

\section{Results}

\section{Oak Response and Stand Structure}

Within control plots, mean DBH changed from 13.65 inches (+/-5.57) to 14.11 inches (+/-6.28) between study years. Within released plots mean DBH changed from 11.15 inches $(+/-5.11)$ to 12.4 inches (+/-7.46) from 2003 to 2017 respectively. Mean height of control trees increased from $29.26 \mathrm{ft}(+/-9.88)$ to $33.38 \mathrm{ft}(+/-10.78)$, while released stands remained relatively consistent, from $32.19 \mathrm{ft}(+/-13.28)$ to 31.92 (+/-10.93) from 2003 to 2017. Lastly, mean livecrown ratio in control plots changed from $34.08 \%(+/-16.93)$ to $36.59 \%(+/-14.15)$, while 
released plots changed from 40.64\% (+/-11.39) to 39.80\% (+/-12.55) between 2003 and 2017 respectively.

While there was a significant increase in average oak DBH across the entire study between 2003 and 2017, the effect of the release treatment on oak DBH was not significant (period $\mathrm{x}$ site class interaction $\mathrm{p}=0.32$, Table 1 , Figure 2). The release treatments also did not have a significant effect on average height nor on live-crown ratio (Table 1).

Although analyses indicate non-significant results for period $\mathrm{x}$ site class interactions, some differences between treatment groups were still observed within the data. Oregon white oaks in released areas had a $10.87 \%$ increase in average DBH growth between study years, compared to only an increase of $3.37 \%$ observed in control plots (Figure 2). Conversely, Oregon white oaks in control areas had greater increases in average height and live-crown ratio compared to trees in released areas (Figure 2).

In 2017 a total of 11 wildlife nests and 69 tree cavities were observed. Signs of disease were observed on only $2.37 \%$ of trees sampled. However, of the trees with signs of disease $78 \%$ were oaks and the remaining $22 \%$ were either Douglas-fir, or ponderosa

Table 1: BACI results for growth of Oregon white oak trees $(n=119)$. Period $=$ Year; Site Class $=$ Treatment Type; Period $x$ Site Class $=$ interaction of year and treatment type

\begin{tabular}{|c|c|c|c|c|}
\hline Variable & Source & DF & F-value & $\operatorname{Pr}>F$ \\
\hline \multirow[t]{4}{*}{$\mathrm{DBH}$} & Period & 1 & 5.5776 & 0.01837 \\
\hline & Site Class & 1 & 27.6063 & $1.79 \mathrm{E}-07$ \\
\hline & $\begin{array}{l}\text { Period x } \\
\text { Site Class }\end{array}$ & 1 & 0.9833 & 0.3216 \\
\hline & Residuals & 1069 & & \\
\hline \multirow[t]{4}{*}{ Height } & Period & 1 & 1.348 & 0.2465 \\
\hline & Site Class & 1 & 0.1484 & 0.7003 \\
\hline & $\begin{array}{l}\text { Period x } \\
\text { Site Class }\end{array}$ & 1 & 2.7011 & 0.1013 \\
\hline & Residuals & 303 & & \\
\hline \multirow{4}{*}{$\begin{array}{l}\text { Live- } \\
\text { crown } \\
\text { ratio }\end{array}$} & Period & 1 & 0.382 & 0.536991 \\
\hline & Site Class & 1 & 8.6632 & 0.003498 \\
\hline & $\begin{array}{l}\text { Period x } \\
\text { Site Class }\end{array}$ & 1 & 1.0824 & 0.29899 \\
\hline & Residuals & 303 & & \\
\hline
\end{tabular}
pine.
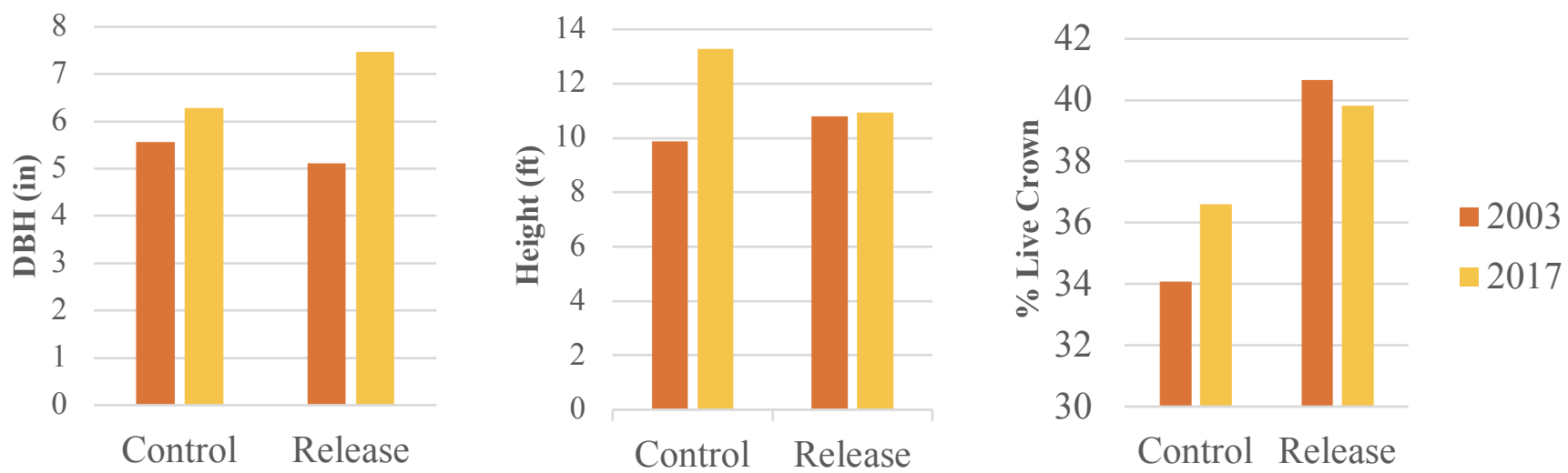

Figure 2: Average DBH, height, and live-crown ratio of Oregon white oak in treatment areas between study years. 


\section{Seedlings and Saplings}

In $2003,34 \%$ of plots had no evidence of tree regeneration, whereas in 2017 only $13 \%$ of plots had no observed regeneration. For both study years Douglas-fir and oak seedings were the most abundant, at $11 \%$ and $51 \%$ in 2003 and $11 \%$ and $66 \%$ in 2017 respectively. Seedling and tree regeneration in 2017 was abundant across all sites, however released plots had increases four times greater than control plots (Figure 3).

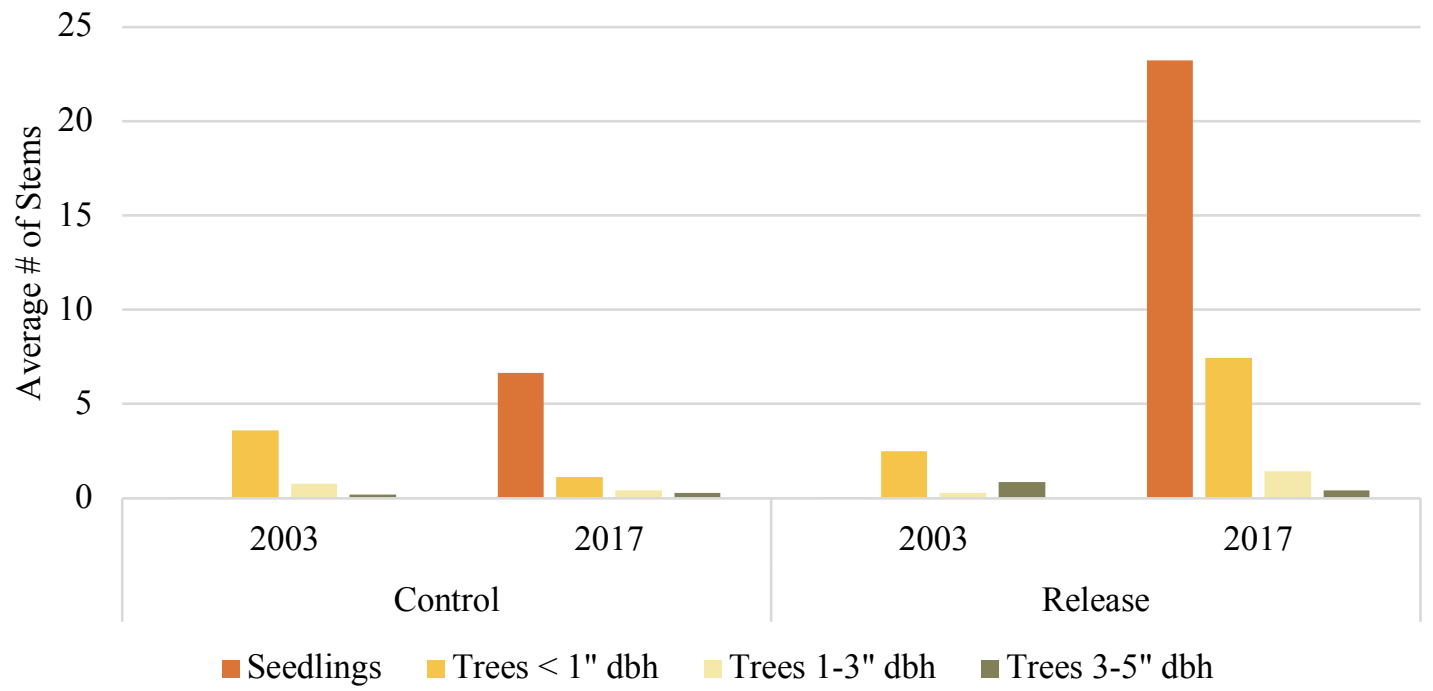

Figure 3: Comparison of average number of stems per plot between study years and treatment types.

BACI results indicated seedling and sapling recruitment was significantly influenced by period $\mathrm{x}$ treatment interaction, while average stem height was not significantly influenced by the interaction (Table 2). 
Table 2: Seedling and saplings BACI design results $(n=294)$. Period $=$ Year; Site Class $=$ Treatment Type; Period $x$ Site Class $=$ interaction of year and treatment type

\begin{tabular}{|c|c|c|c|c|}
\hline Variable & Source & DF & F-value & $\operatorname{Pr}>\mathrm{F}$ \\
\hline \multirow[t]{4}{*}{ Seedling tally } & Period & 1 & 0.3929 & 0.53128 \\
\hline & Site Class & 1 & 0.2449 & 0.62107 \\
\hline & Period x Site Class & 1 & 5.852 & 0.01617 \\
\hline & Residuals & 294 & & \\
\hline \multirow[t]{4}{*}{ Trees $<1 "$ dbh } & Period & 1 & 0.435 & 0.51004 \\
\hline & Site Class & 1 & 4.4807 & 0.03512 \\
\hline & Period x Site Class & 1 & 5.3234 & 0.02174 \\
\hline & Residuals & 294 & & \\
\hline \multirow[t]{4}{*}{ Trees 1-3" dbh } & Period & 1 & 1.2297 & 0.26838 \\
\hline & Site Class & 1 & 1.8676 & 0.1728 \\
\hline & Period x Site Class & 1 & 5.7175 & 0.01743 \\
\hline & Residuals & 294 & & \\
\hline \multirow[t]{4}{*}{ Trees 3-5" dbh } & Period & 1 & 0.9719 & 0.325009 \\
\hline & Site Class & 1 & 7.4062 & 0.00688 \\
\hline & Period x Site Class & 1 & 5.1131 & 0.024476 \\
\hline & Residuals & 294 & & \\
\hline Average stem & Period & 1 & 31.5481 & $4.51 \mathrm{E}-08$ \\
\hline \multirow[t]{3}{*}{ height } & Site Class & 1 & 0.7053 & 0.4017 \\
\hline & Period x Site Class & 1 & 0.01 & 0.9205 \\
\hline & Residuals & 294 & & \\
\hline
\end{tabular}

Evaluating seedling and sapling totals by species type, oaks increased between study years within both treatment types; however, increases in released plots were two times greater than in control plots. Most species had an observable trend of high counts of seedlings with gradually declining counts for the larger diameter class; however, released plots had increases in other woodland species at higher diameter class sizes (Figure 4). 


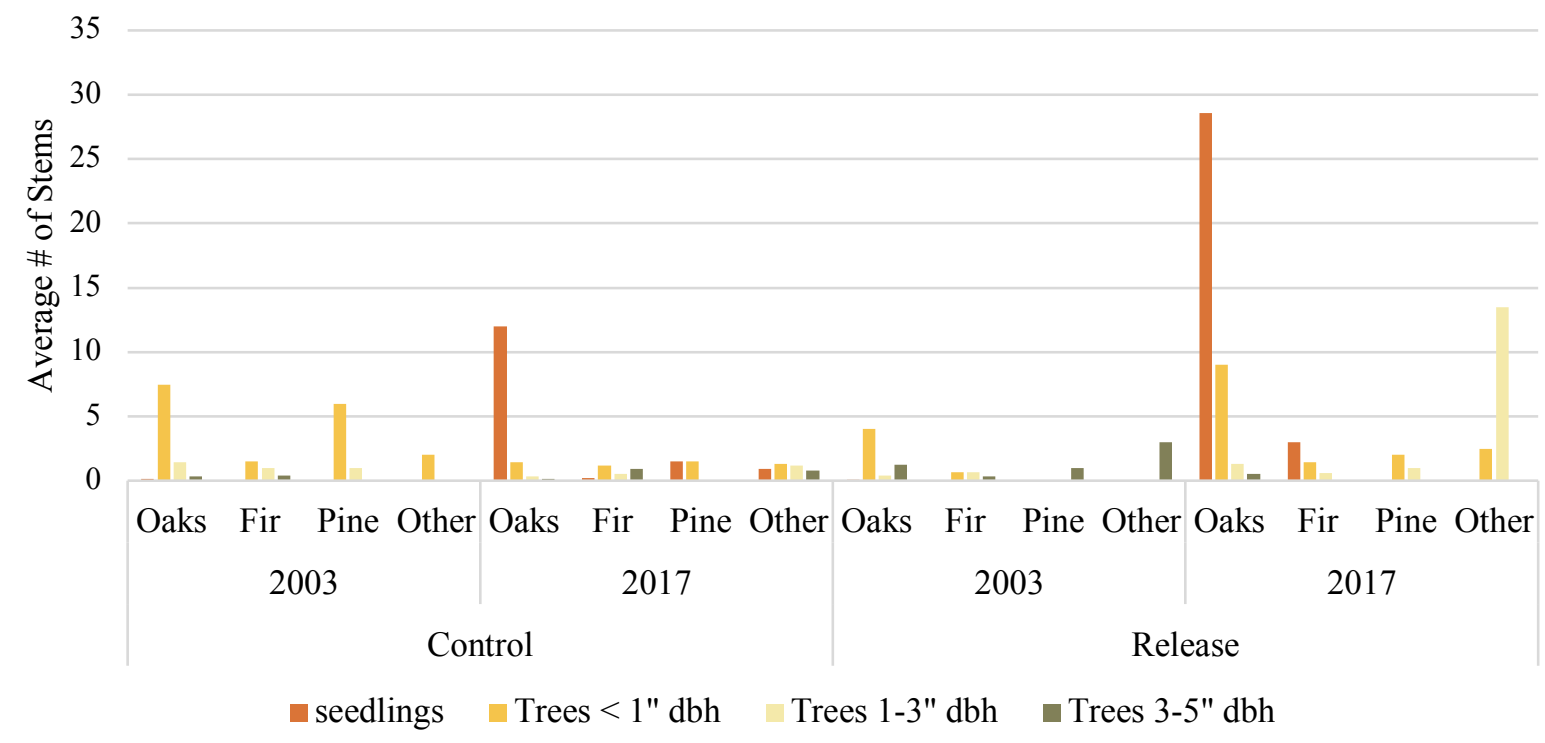

Figure 4: Comparison of average number of stems per plot by species type between study years and treatment types

\section{Stump Sprouts}

A total of 77 Oregon white oak stumps were measured across 16 plots. Of the stumps observed 32 had no sprouts, while 45 had one or more sprouts. Signs of browse was observed on $37 \%$ of sprouting stumps. Stump diameters ranged from 4 inches to 48 inches, and stump height ranged from 4 inches to 36 inches. Average sprout height was 1-foot, with the maximum sprout height of 7-feet. Logistic regression showed a significant relationship between canopy cover and the probability of sprouting $(\mathrm{P}=0.0491)$, with no significant relationship detected for all other variables (slope, aspect, vegetation competition, stump height, diameter, and signs of browse). Canopy coverage of $0-15 \%$ and $30-60 \%$ had the largest proportion of stumps designated with a sprout score of high with 10 or more observed sprouts. Additionally, $15-30 \%$ and $30-60 \%$ canopy cover had greatest total number of sprouting stumps, and the largest proportion of stumps without sprouts (Figure 5).

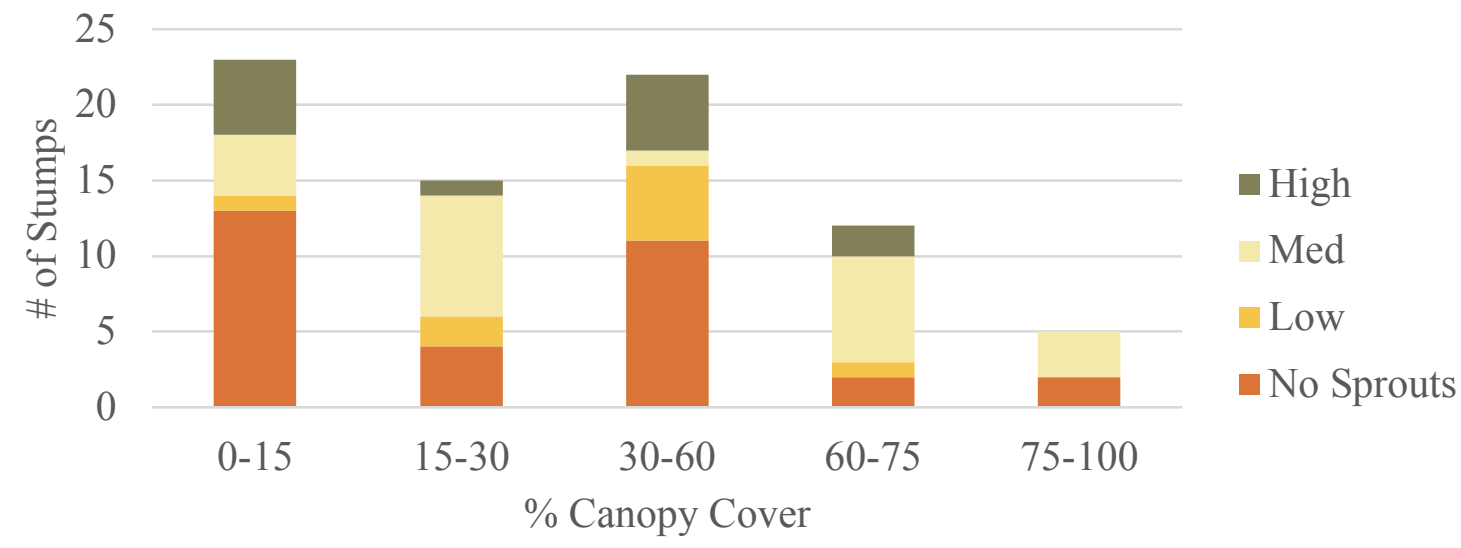

Figure 5: Proportion of each sprout score for each sprouting stump observed by canopy coverage 
The linear regression model indicated no significant differences between the number of sprouts, and stump height and diameter $(\mathrm{P}=$ $0.5602, \mathrm{P}=0.2576$ respectively). Although results indicate no significant differences, some trends can be observed within the data. White oak stumps with diameters larger than 9-inches had relatively fewer sprouts compared to stumps less than 9-inches. Additionally, white oak stumps had the largest number of sprouts at cut heights of 8-inches (Figure 6).

\section{Fuel Loads}

Average tons per acre for 1-, 10-, and 100-hour fuels in control and release plots decreased between study years. Within control plots, mean 1-hour fuels changed from 0.68 tons/acre (+/- 0.61$)$ to 0.04 tons/acre (+/- 0.08) in 2017.

Average 10-hour and 100-hour fuels changed from 0.74 tons/acre (+/- 0.6) to 0.11 tons/acre (+/$0.27)$, and 0.75 tons/acre $(+/-0.6)$ to 0.17 tons/acre $(+/-0.27)$ respectively. Within release plots, mean 1-hour fuels changed from 0.78 tons/acre (+/- 0.6) to 0.06 tons/acre $(+/-0.07)$ in 2017. Average 10-hour and 100-hour fuels changed from 1.13 tons/acre ( $+/-1.53)$ to 0.061 tons/acre (+/- 0.07), and 0.97 tons/acre (+/- 0.45) to 0.31 tons/acre (+/- 0.35) respectively (Figure 7). 1000hour fuels remained relatively constant within both treatment types across study years, similarly for average duff depths. However, average fuel height increased within both treatment types.

A comparison of fuel and woody debris between study years showed substantial decreases in 1-, 10-, and 100- hour fuel loads. Fuel loads in the 1- and 10-hour classes are the most important in estimating fire risk, as these fuel types largely determine rate of spread. Average levels of the combined tons/acre in 2017 for these classes did not exceed 0.136 tons per acre. In contrast, 2003 combined average levels totaled 1.5 tons per acre. Levels above 3 tons/acre are considered to be excessive and pose high risk for rapid fire spread in the case of a wildfire (Integrated Resource Management 2003). The combined total average for all fuel classes in 2017 was 1.4 tons per acre, compared to the 4 tons per acre in 2003. Average duff depths experienced slight increases between study years from $0.41 \mathrm{~mm}(+/-0.22)$ to $0.79 \mathrm{~mm}(+/-0.81)$ in control plots and $0.55 \mathrm{~mm}(+/-0.34)$ to $1.31 \mathrm{~mm}(+/-1.23)$ in released stands. Fuel heights, however increased within both treatment types across study years from 0.79 feet $(+/-0.81)$ in 2003 , to 9.28 feet $(+/-$ $9.4)$ in 2017 in control plots, and 1.3 feet $(+/-1.07)$ in 2003, to 10.41 feet (+/- 6.4) in 2017 within released stands. (Figure 8). 


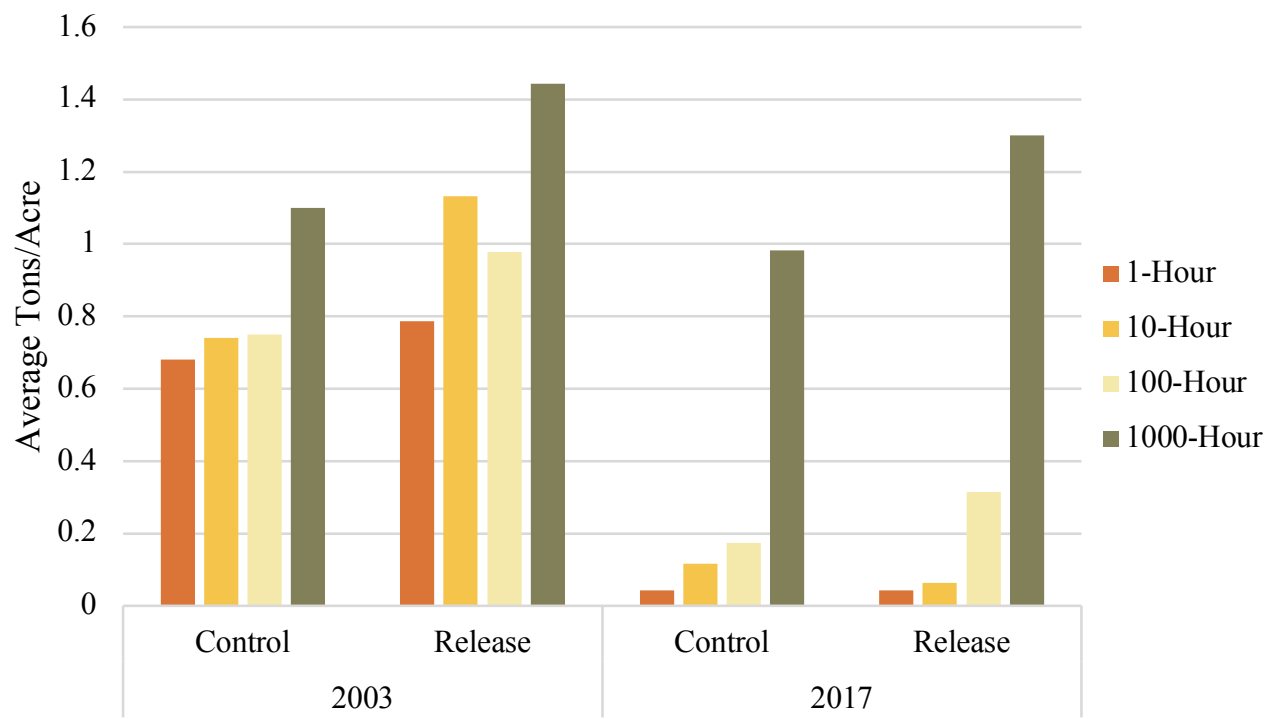

Figure 7: Distribution of fuel classes measured in average tons per acre between study years and treatment types.

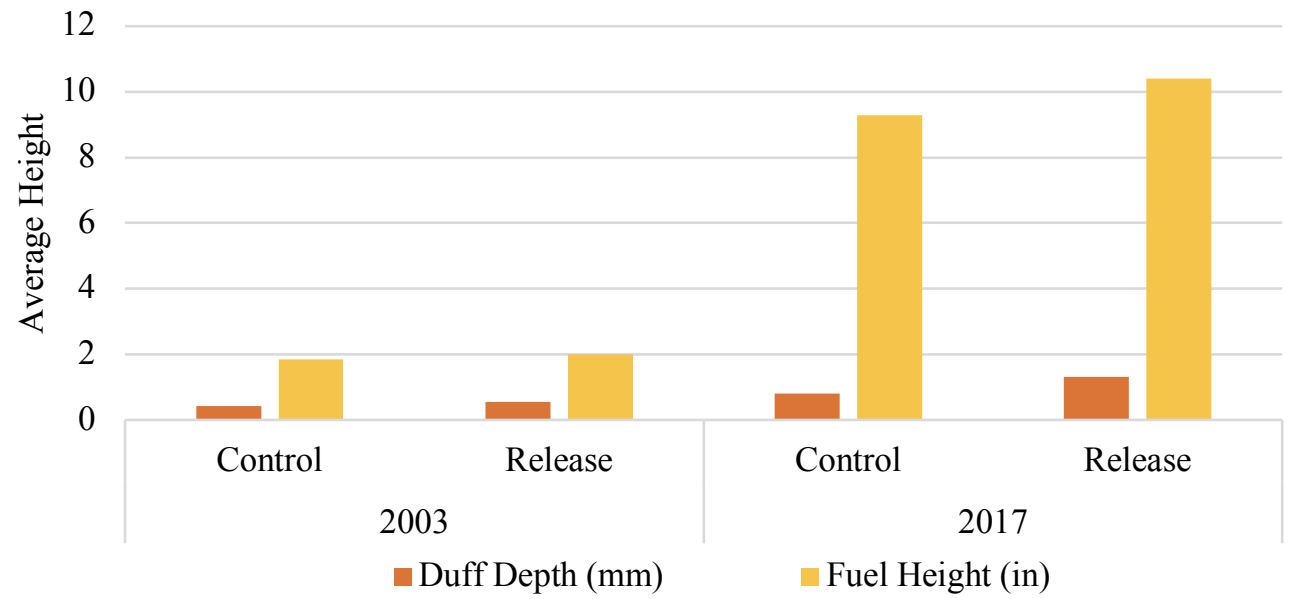

Figure 8: Average duff depth and fuel height between study years and treatment types. 
BACI design results for treatment type (site class) and period $\mathrm{x}$ site class interaction were not significant for any of the fuel class or duff depth and fuel height. However, BACI results did confirm significant differences for all variables between study years (Table 3 ).

Table 3: Fuel loads and coarse woody debris BACI design results $(n=38)$. Period $=$ Year; Site Class $=$ Treatment Type; Period $x$ Site Class = interaction of year and treatment type

\begin{tabular}{|c|c|c|c|c|}
\hline Variable & Source & DF & F-value & $\operatorname{Pr}>F$ \\
\hline \multirow[t]{4}{*}{ 1-Hour } & Period & 1 & 45.0183 & $6.09 \mathrm{E}-08$ \\
\hline & Site Class & 1 & 0.5918 & 0.4465 \\
\hline & Period x Site Class & 1 & 0.5689 & 0.4533 \\
\hline & Residuals & 38 & & \\
\hline \multirow[t]{4}{*}{ 10-Hour } & Period & 1 & 36.9717 & 4.42E-07 \\
\hline & Site Class & 1 & 1.5815 & 0.2162 \\
\hline & Period x Site Class & 1 & 2.658 & 0.1113 \\
\hline & Residuals & 38 & & \\
\hline \multirow[t]{4}{*}{ 100-Hour } & Period & 1 & 19.7518 & $7.40 \mathrm{E}-05$ \\
\hline & Site Class & 1 & 1.75 & 0.1938 \\
\hline & Period x Site Class & 1 & 0.0981 & 0.7558 \\
\hline & Residuals & 38 & & \\
\hline \multirow[t]{4}{*}{ 1000-Hour } & Period & 1 & 0.162 & 0.6896 \\
\hline & Site Class & 1 & 1.0601 & 0.3097 \\
\hline & Period x Site Class & 1 & 0.0017 & 0.9671 \\
\hline & Residuals & 38 & & \\
\hline \multirow[t]{4}{*}{ Duff Depth } & Period & 1 & 6.3698 & 0.01591 \\
\hline & Site Class & 1 & 2.335 & 0.13478 \\
\hline & Period x Site Class & 1 & 0.7802 & 0.38262 \\
\hline & Residuals & 38 & & \\
\hline \multirow[t]{4}{*}{ Fuel Height } & Period & 1 & 18.4387 & 0.0001169 \\
\hline & Site Class & 1 & 0.1224 & 0.7283639 \\
\hline & Period x Site Class & 1 & 0.0675 & 0.7964367 \\
\hline & Residuals & 38 & & \\
\hline
\end{tabular}




\section{Snags}

A total of 332 snags were observed in 2003 and only 193 snags in 2017 . There was an increase in transects with no snag observations from $7 \%$ in 2003 and $37 \%$ in 2017 . A comparison of snag characteristics between study years documents a gradual progression of snag decay. Average snag diameter declined by $35 \%$ from 11.62 inches to 7.47 inches in 2017 . Evaluating the distribution of total snags by decay class reveals a similar pattern of decay, with 2003 having a larger proportion of snags in Decay Class 3, whereas 2017 had a larger proportion of total snags in Decay Classes 4 and 5 (Figure 9).

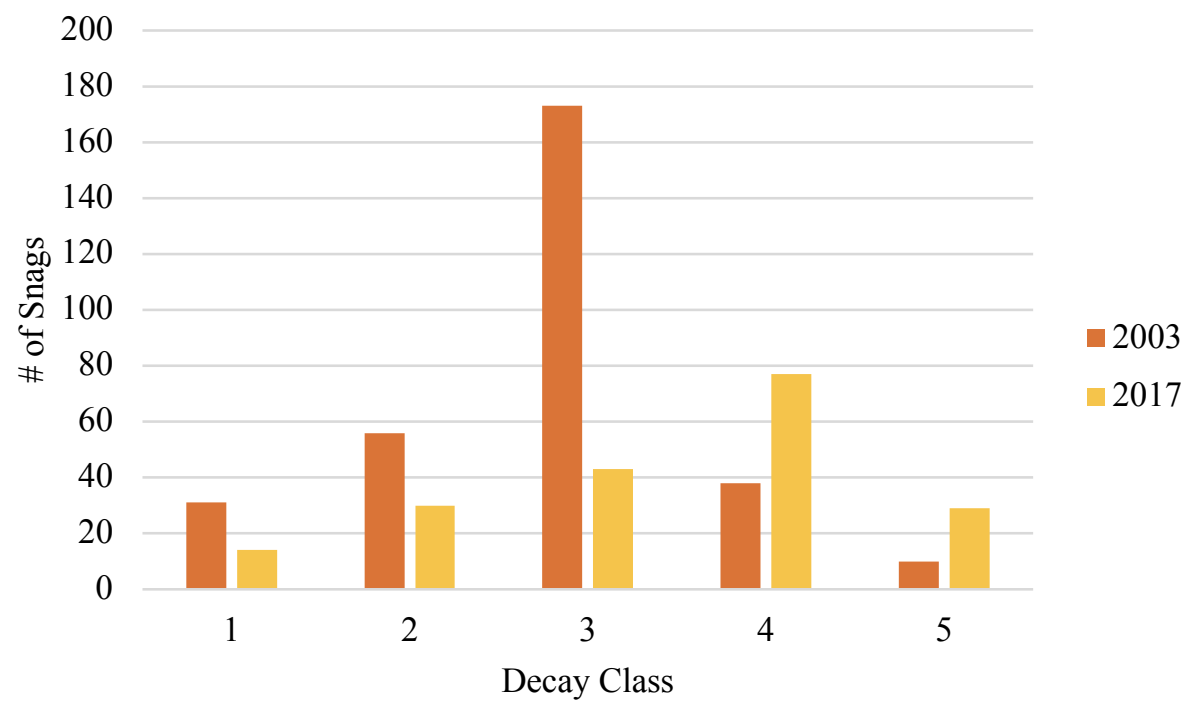

Figure 9: Decay class distribution among observed snags within study years.

Examining decay class distribution by species type reveals the majority of snags observed between both study years were oak, at $58 \%$ in 2003 and $43 \%$ in 2017 . Oaks species compromised the majority of snags observed within Decay Class 3 in 2003 and Decay Class 4 in 2017 (Figure 10).

2003

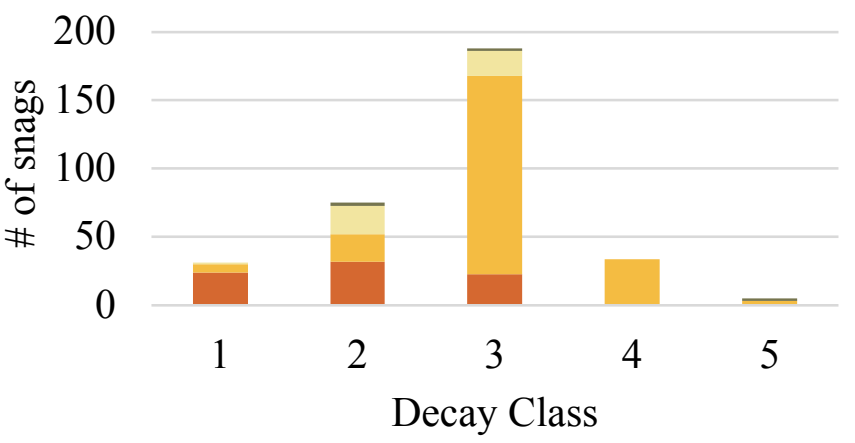

2017

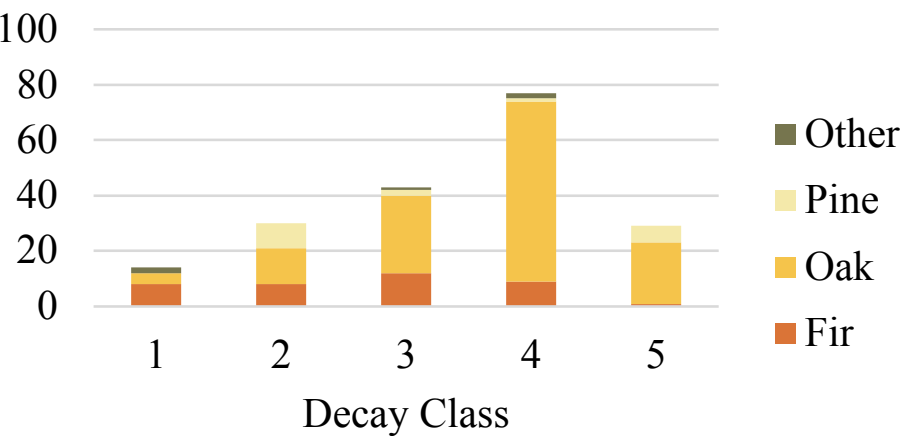

Figure 10: Decay class distribution between study years by species type 


\section{Discussion}

\section{Oregon White Oak Stand Structure}

The desired future condition of oak woodlands following release treatments is a mosaic of tree age classes spatially patterned to mimic both individual and group mortality events. In 2003, one of the primary goals was to create a stand density that would allow for development of more open grown tree structures. Fourteen years later, managers are beginning to understand the complexity of dry oak systems, the diversity of stand structures that are shaped by biophysical factors such as soil type, aspect, precipitation, fire, grazing, wind exposure, and human behaviors, and the value these diverse structures may present to associated flora and fauna. Determination of a desired future condition is therefore not as straight forward as managers believed, the previously held notions largely informed by science on Willamette Valley and Puget Trough oak systems, which are distinctly different from east Cascade oak systems.

Oregon white oak is a very slow growing species in both diameter and height, and the lack of statistical significance may be a result of the short timeframe between study years (Stein 1990). The growth response of Oregon white oak trees, while not statistically significant, does indicate post-release responses are occurring and are subtly shifting the stand characteristics towards a larger diameter, more open-grown structure. It has been observed in other studies that following overstory density reduction, available soil water in oak stands can increase due to the combined effects of decreased interception of rainfall and reduced stand-level transpiration (Breda et al. 1995). This difference in diameter growth between control and treatment areas supports the idea that oak trees would receive the greatest increase in above- and below-ground resources from a release (Devine and Harrington 2013). Additionally, slow diameter growth is often indicative of long-term stresses, such as those caused by high levels of competition. Gould et al. (2011) modeled Oregon white oak sensitivity to competition and subsequent impacts to diameter growth. They observed a reduction of $25 \%$ in tree diameter growth in high density stands, compared to an open-grown stand density. They concluded that high levels of competition may be more likely to reduce diameter growth in order to maintain adequate functional xylem development and transport. These studies are based on sites west of the Cascades. As biophysical factors and growth rates are different in the East Cascade ecoregion, further study is warranted.

The lack of statistical significance on height may also be due to the short time period between surveys however, this trend may be a result of released oaks investing in diameter growth and development of epicormic branching as opposed to height as trees in competition for light resources characteristically do. Competition in higher density stands may reduce the amount of diameter growth of Oregon white oaks and increase the rate of vertical growth in order to maximize access to above-ground resources (Gould et al. 2011). Similarly, oak live-crown ratio was not significantly affected by treatments. It is possible that changes to release stand crowns was not well captured by our measurements. For example, quantifying foliage density or individual tree leaf areas may have provided more details regarding differences between treatment types. Moreover, crown expansion associated with epicormic branching was largely associated with treated areas. Similar studies report large increases in emerging epicormic branches 5-years post-release, and at 10-years a few branches are still present (Devine and Harrington 2006). Based on crown development patterns in other species it is likely that these early branches originating as epicormic sprouts following release are not incorporated into the 
overall crown area. These branches may not be increasing live-crown area vertically but rather horizontally which would not have been captured by our methods.

\section{Seedlings and Saplings}

Counts of oak seedlings and saplings across all treatment types increased between study years; however, control seedlings counts were significantly less than those in released stands. Establishment and vigor of oaks can be increased through management treatments by providing greater access to sunlight and water (Janzen and Hodges 1985; Davis et al. 1998). In our study area, the increases in white oak regeneration vigor within the released stands was likely influenced by the increased exposure to direct sunlight (Dillaway et al. 2007; Devine and Harrington 2013). Although shade intolerant at maturity, Oregon white oaks are able to germinate and grow in shade or sun. Typically, the first few years post disturbance, tens of thousands of small seedlings and saplings complete for space in the canopy; however, a gradual decline becomes apparent a few years post-disturbance (Dey et al. 2008). The gradual decline of oaks past the seedling stage could be the result of increased seedling competition for light and water availability. To survive warm, dry summers oak seedlings must penetrate deep enough in the soil profile by midsummer to access sufficient water resources (Devine et al. 2007). Released plots may have also increased overall forest diversity as several tree species not focused on in this analysis appeared to benefit from the treatments. Species such as bigleaf maple (Acer macrophyllum), red alder (Alnus rubra), and bitter cherry (Prunus emarginata) all increased in abundance following release.

\section{Stump Sprouts}

There are several factors that can be detrimental to oak seedlings from establishing following release. One of the biggest concerns for land managers seeking to reduce stem density of oaks following thinning is the occurrence of stump sprouts. In general stump sprouts are an important source of oak regeneration following a disturbance. They are the fastest-growing and most competitive source of oak reproduction (Johnson et al. 2002). The logistic regression model showed a significant relationship between canopy cover and sprouting probability may be in response to increases in light availability. A primary cause of oak regeneration failure is low light level at less than five percent (Dey et al. 2008). This may explain the steep drop in the number of sprouting stumps at the highest canopy coverage of 75-100\%. However, the degree of sprouting may also be affected by variables not captured in this analysis, or significant variables measured in this study that may have gone undetected due to the relatively small sample size.

Models developed by Gould et al. (2007) to predict sprouting ability among oak species show that white oak rapidly loses sprouting ability with increasing diameter. While this observation was not proven statistically significant within our study, the number of sprouts did decline with increasing stump diameter. It is important to consider that oak regeneration methods result in a more reliable and predictable method of regeneration (Steiner et al. 2008). Stump sprouts have the potential to grow more quickly within the first few years after release compared to newly established individuals, due to the large root mass and storage of carbohydrates (Sands and Abrams 2009). Periodic thinning of sprouts relatively early after harvest may improve growth rates of seedlings and create a single dominant stem as opposed to unthinned sprouting that is likely to lead to a ring of similar sized stems around the parent stump 


\section{Fuel Loads}

Prior to release, fuel loads within study sites indicated a moderate risk of habitat loss due to catastrophic fire. A stated goal of the project was to reduce fuel loads and ladder fuels, and to provide more fire secure habitat. Release treatments can oftentimes have short and long-term impacts on fuel loads. Opening forest canopies increases the amount of sun light reaching the forest floor, creating conditions that may lead to the proliferation of grass and shrub fuels and loss of humidity. The removal of fuels following release treatments can dramatically decrease the tons per acre of surface fuels on the study sites. Generally, burn piles are considered the most effective way of removing material from the forest following release (Peterson et al. 2005). The lack of statistical significance between the interaction of year and treatment may be due to the small sample size. Data loss in 2017 resulted in entire stands with no plot data. The removal of these plots from the analysis limits the findings; however, some trends can still be observed. The reduction of 1- and 10-hour fuels through the post-treatment burns piles dramatically reduced these fuel classes between study years. Larger, 1000-hour fuels remained relatively constant between study years. While this material can be viewed as a fire hazard, down woody material in this size class does not contribute to catastrophic fire behavior and also serves many important functions within forested communities. Logs and other large woody debris occur on the floor of most forest ecosystems. These features provide diversity in the environment, contribute to important nutrient cycles, and provide critical habitat to a wide variety of species (Maser et al. 1979; Larsen and Morgan 1998). Due to relative influence of terrain and weather on fire spread and severity it is difficult to develop precise quantitative guidelines for fuel treatments. A majority of the literature supports the effectiveness of fuel treatments in reducing the risk of habitat destroying fires (Brown 2002; Carey and Schumann 2003), and in simulation modeling (Finney 2001; Stephens 1998). Areas with the highest fire risk were prioritized for treatments, resulting in approximately 20 tons per acre of organic material burned to reduce management impacts from the study sites. Rate of spread and fireline intensity in thinned stands are usually significantly reduced when thinning is accompanied by a reduction in surface fuels (Peterson et al. 2005).

While fuel reduction treatments were successful in lowering the amount of fuel per acre, the observed increase in fuel height between study years and treatment type can be a risk during wildfires. Taller fuels, or ladder fuels, can increase the probability of surface fires developing into crown fires. Crown fires are generally considered the primary threat to ecological and human values and are the primary challenge for land managers (Peterson et al. 2005). Tree canopies are the primary stratum involved in crown fires, and the spatial continuity and density of tree canopies combined with fuel loads determine the rate of fire spread and severity. However, although taller fuels can influence the development of crown fires, other studies show reductions of fuel load and management of surface fuels can decrease impacts from crown fires and increase the likelihood that the stands will survive a wildfire (Agee and Skinner 2005).

\section{Snags}

One primary goal of the implemented release was to provide greater number and diversity of dead wood structures. Many animal species are dependent on these standing dead trees for some aspect of their life history. There are many factors that could explain the observed decrease in snags in 2017. The crew engaged to thin the treatment area was accustomed to working on fuels reduction projects that typically require snag removal. The crew removed snags until the project 
manager notified crews to cut only the live trees that were marked for removal. Additionally, some snags may have been lost during the felling of removed trees. Lastly, the exact transect used in 2003 was not the same transect walked in 2017, which could account for some of the variance between 2003 and 2017 snag counts.

\section{Management Recommendations}

Although Oregon white oak can survive for centuries under favorable conditions (Stein 1990), its biological characteristics of shade intolerance and reliance on the most recent two years of ring growth for water transport means that it is very vulnerable to competition (Gould et al. 2011). Our findings indicate that a single-entry release of suppressed Oregon white oak from conifer encroachment can decrease stand density and improve growth. Signs of "thinning shock" which has been observed in other studies was not observed within the released stands (Harrington and Reukema 1983). While the response was not significant, growth trends between the two treatment types indicate stand release as a viable option of encouraging development of larger diameter, viable trees within Oregon white oak woodlands. Stem density may ultimately increase in the long term due to stump sprout and seedling recruitment, though further study is needed to understand this dynamic in the longer term, with and without grazing activity. Additionally, while conifer and pine seedling average counts per plot were less than oak observations, these species can grow at a rate three to five times faster than that of Oregon white oak (Sprague and Hansen 1946). While juvenile white oaks have the ability to withstand low light intensities, once oak saplings become overtopped by faster growing conifer species they will be unable to successfully developed into mature trees (Silen 1958; Miller 1985; Kertis 1986). Due to the slower growing nature of oaks, I recommend that Columbia Land Trust continue to monitor released stands to limit future conifer encroachment, and to continue to evaluate the long-term effects of stand release on oak growth and vigor. Future release treatments should focus on areas with priority Oregon white oak trees that are particularly encroached upon by conifers that threaten to shade out oaks. Refer to Appendix A: Logging Camp Canyon Stand Map and Seedling Map; Appendix B: Dillacort Creek Stand Map and Seedling Map for property specific locations.

Multiple iterations of periodic thinning of oak stump sprouts could help to reduce the number of sprouts over time. While herbicide applications were completed on some stumps during the release many of these stumps sprouted. Consulting with a Certified Pesticide Applicator on future treatments may help determine the appropriate level of application to limit sprouting. Not all oak stumps did produce sprouts following harvest, and although not statistically evident within our study, it has been observed within other studies that stump size can influence sprouting capacity. Focusing follow-up monitoring and stump sprout control treatments on the stumps demonstrating higher rates of sprouting may also help to reduce the amount of stump sprouting over time (Dey et al. 2008; Weigel and Peng 2002). Refer to Appendix A: Logging Camp Canyon Stump Sprout Map; Appendix B: Dillacort Creek Stump Sprout Map for property specific locations.

The fuel treatments conducted after the release helped create conditions that effectively reduced the amount of surface fuels across the study sites. Future release treatments should continue to utilize pile burns or offsite transfer for use as biofuels as a means of fuel reduction. Additionally, fuel treatments should also include follow up treatments within areas that contain the greatest 
proportion of ladder fuels and managers should evaluate potential crown fire risk. To reduce the probability of crown fires, fuel treatments should consider how canopy base height, canopy bulk density, and continuity of tree canopies affect the initiation and propagation of crown fires. Additionally, future fuel treatments should consider how site factors, such as topography and weather patterns, may influence fire spread and risk in the area. Refer to Appendix A: Logging Camp Canyon Stand Surface Fuels; Appendix B: Dillacort Creek Stand Surface Fuels.

Snags are often limited features across the landscape yet have a high importance for many species. There is growing interest in the creation of snags by artificial means among forest managers in order to mitigate snag densities and to conserve cavity-dependent species (Kilgo and Vukovich 2014). There are many common methods of snag creation utilized in forest management, with varying reported levels of success (Lewis 1998; DeBell et al. 1997; Brandeis et al. 2002). Different methods of snag creation can impact the longevity and habitat benefits of artificial snags, with some treatment methods decreasing the useful lifespan of created snags (Brandeis et al. 2002). While herbicide treatments expedite the onset of death, they also shorten the functional longevity of the created snag. Initiation of decay takes longer with girdling treatments, but typically results in a longer useful life as a wildlife tree (Brandeis et al. 2002). Incorporating artificially created snags through girdling in future release treatments may help to increase snag abundance over time.

\section{Proposed Protocol Changes}

While it is important to maintain consistent methods within long-term studies, I propose the following changes to the protocol to help with future data collection and analysis: First, utilizing crown area indexes in addition to live-crown ratios to capture changes to canopy coverage. This index is obtained by multiplying vertical crown diameter by the horizontal crown diameter. This change would involve one additional measurement in the field of the canopy's horizontal diameter. This change may help provide a more detailed picture of how canopies change in response to release treatments because it accounts for growth along two planes. Secondly, I propose that stump sprout vigor scores be changed from a categorical variable (low, medium, high) to a numerical variable of counts per stump. In order to analyze sprout vigor, dummy codes were used to represent the different levels. Using actual count data may be more beneficial in distinguishing differences among sprouting stumps and how factors such as diameter, height and canopy cover influence sprouting probabilities. 


\section{Literature Cited}

Agee, J. K. (1997). Fire management for the 21st century. Creating a forestry for the 21st century. Island Press, Washington, DC, 191-201.

Agee, J. K., \& Skinner, C. N. (2005). Basic principles of forest fuel reduction treatments. Forest ecology and management, 211(1-2), 83-96.

Brandeis, T., Newton, M., Filip, G., \& Cole, E. (2002). Cavity-Nester Habitat Development in Artificially Made Douglas-Fir Snags. The Journal of Wildlife Management, 66(3), 625-633.

Bréda, N., Granier, A., \& Aussenac, G. (1995). Effects of thinning on soil and tree water relations, transpiration and growth in an oak forest (Quercus petraea (Matt.) Liebl.). Tree physiology, 15(5), 295-306.

Brown, J. K. (1974). Handbook for inventorying downed woody material. Gen. Tech. Rep. INT16. Ogden, UT: US Department of Agriculture, Forest Service, Intermountain Forest and Range Experiment Station. 24 p., 16.

Brown, R. T. (2000). Thinning, fire, and forest restoration: A science-based approach for national forests in the interior Northwest. Defenders of Wildlife.

Carey, A. B., Wilson, T. M., \& Bayrakci, R. (2001). Current status of the western gray squirrel population in the Puget Trough, Washington.

Carey, H., \& Schumann, M. (2003). Modifying wildfire behavior-The effectiveness of fuel treatments. The Forest Trust, 16.

Chappell, C. B., \& Crawford, R. C. (1997). Native vegetation of the South Puget Sound prairie landscape. Ecology and conservation of the South Puget Sound prairie landscape. The Nature Conservancy of Washington, Seattle, WA, 107-122.

Chappell, C. B., Crawford, R. C., Barrett, C., Kagan, J., Johnson, D. H., O’Mealy, M., ... \& O’Neil, T. A. (2001). Wildlife habitats: descriptions, status, trends, and system dynamics. Wildlife habitat relationships in Oregon and Washington.

Christy, J. A., \& Alverson, E. R. (2011). Historical vegetation of the Willamette Valley, Oregon, circa 1850. Northwest Science, 85(2), 93-107.

Crawford, R. C., \& Hall, H. (1997). Changes in the south Puget prairie landscape. Ecology and conservation of the south Puget sound prairie landscape. The Nature Conservancy, Seattle, WA, 11-15.

Davis, M. A., Wrage, K. J., \& Reich, P. B. (1998). Competition between tree seedlings and herbaceous vegetation: support for a theory of resource supply and demand. Journal of Ecology, 86(4), 652-661. 
DeBell, D. S., Curtis, R. O., Harrington, C. A., \& Tappeiner, J. C. (1997). Shaping stand development through silvicultural practices. Creating a forestry for the 21st century: the science of ecosystem management. Edited by KA Kohm and JF Franklin. Island Press, Washington, DC, 141-149.

Devine, W. D., \& Harrington, C. A. (2006). Changes in Oregon white oak (Quercus garryana Dougl. ex Hook.) following release from overtopping conifers. Trees, 20(6), 747-756.

Devine, W. D., \& Harrington, C. A. (2013). Restoration release of overtopped Oregon white oak increases 10-year growth and acorn production. Forest ecology and management, 291, 87-95.

Devine, W. D., Bower, A., Miller, J., \& Aubry, C. (2013). Oregon white oak restoration strategy for National Forest System lands east of the Cascade Range. Olympia, WA: US Department of Agriculture, Forest Service. Pacific Northwest Region.

Devine, W. D., Harrington, C. A., \& Leonard, L. P. (2007). Post-Planting Treatments Increase Growth of Oregon White Oak (Quercus garryana Dougl. ex Hook.) Seedlings. Restoration Ecology, 15(2), 212-222.

Dey, D. C., Miller, G. W., \& Kabrick, J. M. (2008). Sustaining northern red oak forests: managing oak from regeneration to canopy dominance in mature stands. UNITED STATES DEPARTMENT OF AGRICULTURE FOREST SERVICE GENERAL TECHNICAL REPORT $P N W, 733,91$.

Dillaway, D. N., Stringer, J. W., \& Rieske, L. K. (2007). Light availability influences root carbohydrates, and potentially vigor, in white oak advance regeneration. Forest ecology and management, 250(3), 227-233.

Dunwiddie, P. W., \& Bakker, J. D. (2011). The future of restoration and management of prairieoak ecosystems in the Pacific Northwest. Northwest Science, 85(2), 83-92.

Finney, M. A. (2001). Design of regular landscape fuel treatment patterns for modifying fire growth and behavior. Forest Science, 47(2), 219-228.

Foster, J. R., \& Shaff, S. E. (2003). Forest colonization of Puget lowland grasslands at Fort Lewis, Washington. Northwest Science, 77(4), 283-296.

Gould, P. J., Fei, S., \& Steiner, K. C. (2006). Modeling sprout-origin oak regeneration in the central Appalachians. Canadian journal of forest research, 37(1), 170-177.

Gould, P. J., C. A. Harrington, and W. D. Devine. (2011). Growth of Oregon white oak (Quercus garryana). Northwest Science 85:159-171.

Harrington, C. A., \& Reukema, D. L. (1983). Initial shock and long-term stand development following thinning in a Douglas-fir plantation. Forest Science, 29(1), 33-46. 
Haufler, J. B., Mehl, C. A., \& Roloff, G. J. (1996). Using a coarse-filter approach with species assessment for ecosystem management. Wildlife Society.

Helms, J.A. 1998. The dictionary of forestry. Bethesda, MD: Society of American Foresters. 224 p.

Hunter Jr, M. L. (1990). Wildlife, forests, and forestry. Principles of managing forests for biological diversity. Prentice Hall.

Integrated Resource Management. (2003). Vegetation Current Conditions Report: Logging Camp and Dillacort Creek Conservation Area.

Janzen, G. C., \& Hodges, J. D. (1985). Influence of midstory and understory vegetation removal on the establishment and development of oak regeneration. Forest Service general technical report SO-United States, Southern Forest Experiment Station (USA).

Johnson, P. S., Shifley, S. R., \& Rogers, R. (2002, April). A new book: the ecology and silviculture of oaks. In 13TH CENTRAL HARDWOOD FOREST CONFERENCE (p. 107).

Kertis, J. 1986. Vegetation dynamics and disturbance history of Oak Patch Preserve, Mason County, Washington. Unpubl. Rep. Wash. Dept. Nat. Resour., Olympia. 112pp.

Kilgo, J. C., \& Vukovich, M. A. (2014). Can snag creation benefit a primary cavity nester: response to an experimental pulse in snag abundance. Biological conservation, 171, 21-28.

Landres, P. B., Morgan, P., \& Swanson, F. J. (1999). Overview of the use of natural variability concepts in managing ecological systems. Ecological Applications, 9(4), 1179-1188.

Larsen, E. M., \& Morgan, J. T. (1998). Management recommendations for Washington's priority habitats: Oregon white oak woodlands. Washington Department of Fish and Wildlife.

Lea, T. (2006). Historical Garry oak ecosystems of Vancouver Island, British Columbia, preEuropean contact to the present. Davidsonia, 17(2), 34-50.

Lewis, J. C. (1998). Creating snags and wildlife trees in commercial forest landscapes. Western Journal of Applied Forestry, 13(3), 97-101.

Maser, Chris, Ralph G. Anderson, Kermit Cromack Jr, Jerry T. Williams, and Robert E. Martin. "Dead and down woody material." Wildlife habitats in managed forests: the Blue Mountains of Oregon and Washington. Agric. Handb 553 (1979): 78-95.

Miller, H. A. 1985. Oregon white oak. Pages 275-278 in H. A. Miller and S. H. Lamb., eds. Oaks of North America. Naturegraph Publ., Happy Camp, Calif.

Peterson, D. L., Johnson, M. C., Agee, J. K., Jain, T. B., McKenzie, D., \& Reinhardt, E. D. (2005). Forest structure and fire hazard in dry forests of the western United States. Gen. Tech. 
Rep. PNW-GTR-628. Portland, OR: US Department of Agriculture, Forest Service, Pacific Northwest Research Station. 30 p, 628.

Popescu, V. D., De Valpine, P., Tempel, D., \& Peery, M. Z. (2012). Estimating population impacts via dynamic occupancy analysis of Before-After Control-Impact studies. Ecological Applications, 22(4), 1389-1404.

Sands, B. A., \& Abrams, M. D. (2009). Field Note: Effects of Stump Diameter on Sprout Number and Size for Three Oak Species in a Pennsylvania Clearcut. Northern Journal of Applied Forestry, 26(3), 122-125.

Schwarz, C.J. (2014) Analysis of BACI experiments. In Course Notes for Beginning and Intermediate Statistics. Available at http://www.stat.sfu.ca/ cschwarz/CourseNotes. Retrieved 2018-04-17.

Silen, R. R. (1958). Silvical characteristics of Oregon white oak. USDA Forest Service, Silvical Series 10. Pacific Northwest Forest and Range Experiment Station, Portland, OR.

Sprague, F. L., \& Hansen, H. P. (1946). Forest succession in the McDonald Forest, Willamette Valley, Oregon. Northwest science, 20(4), 89-98.

Stein, W. I. (1990). Quercus garryana Dougl. ex Hook. Oregon white oak. Silvics of North America, 2, 650-660.

Steiner, K. C., Finley, J. C., Gould, P. J., Fei, S., \& McDill, M. (2008). Oak regeneration guidelines for the central Appalachians. Northern journal of applied forestry, 25(1), 5-16.

Thysell, D. R., \& Carey, A. B. (2001). Quercus garryana communities in the Puget Trough, Washington. Northwest Science, 75(3), 219-235.

Ulrich, N. D. (2010). Restoring oak habitats in the southern Willamette Valley, Oregon: a multiobjective tradeoffs analysis for landowners and managers (Doctoral dissertation, University of Oregon)

Weigel, D. R., \& Peng, C. Y. J. (2002). Predicting stump sprouting and competitive success of five oak species in southern Indiana. Canadian Journal of Forest Research, 32(4), 703-712. 


\section{Appendices}

\section{A. Logging Camp Canyon Property Information}

This section includes three property maps and fuel information by stand to assist with management planning. The Stand Structure Map displays plot locations based on species dominance within stand structure, as well as locations with missing 2017 data. The Douglas-fir Seedling and Sapling Map displays plot locations with high counts of Douglas-fir seedling and sapling counts. Lastly, the Stump Sprout Map displays the plot locations measured for stump sprouts with observed sprouting. 
Stand Structure Map

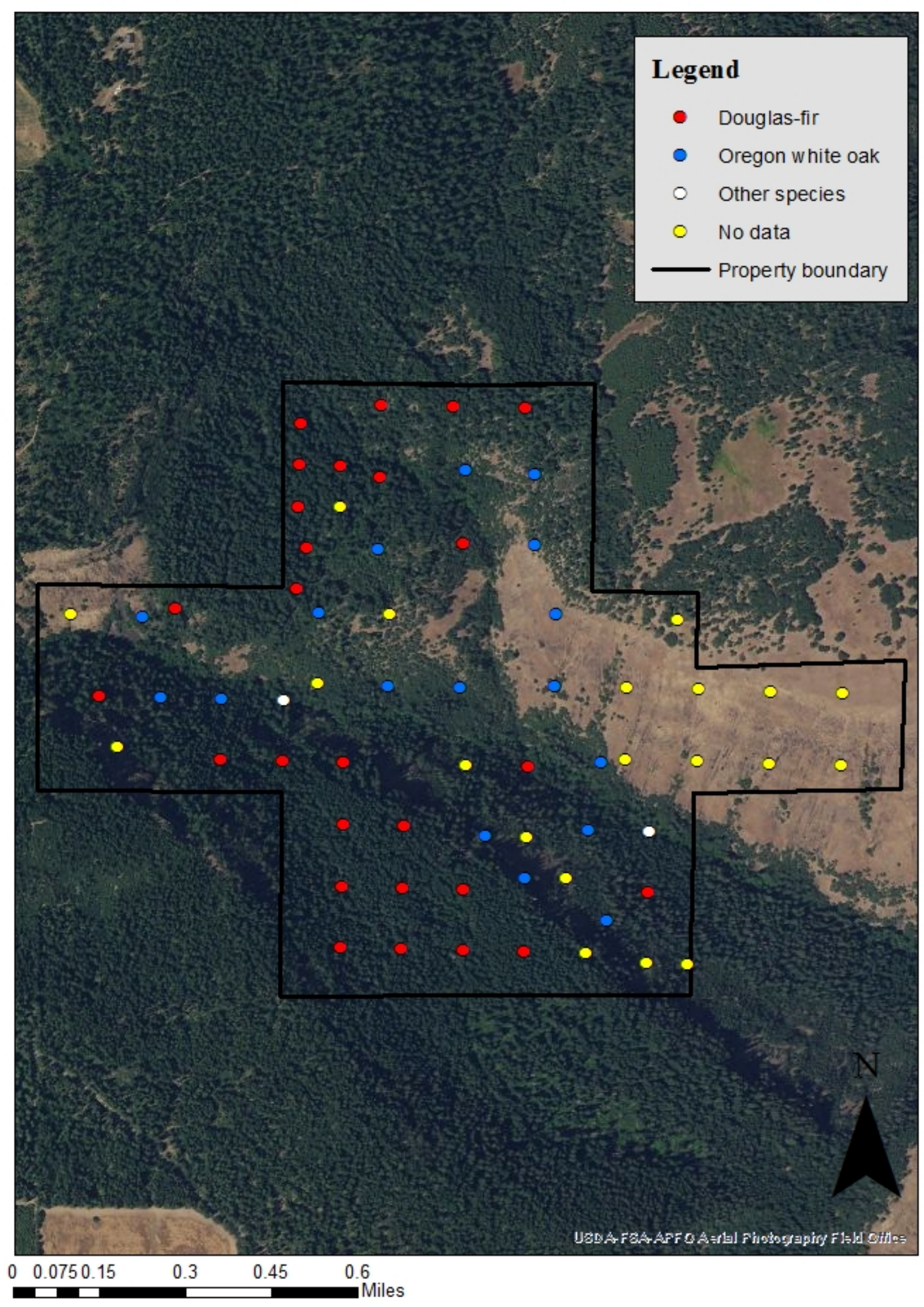


Douglas-fir Seedling and Sapling Map

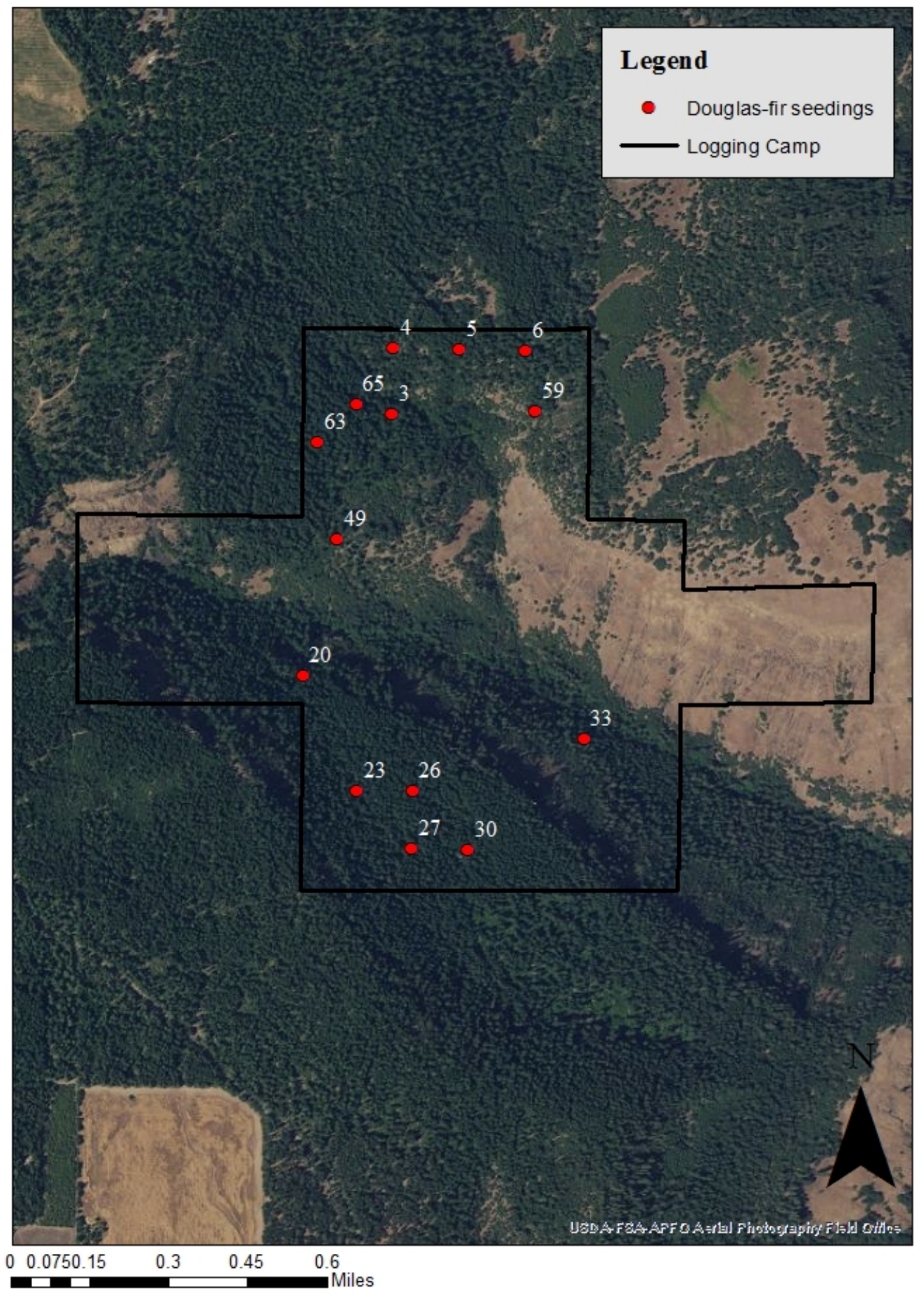




\section{Stump Sprout Map}

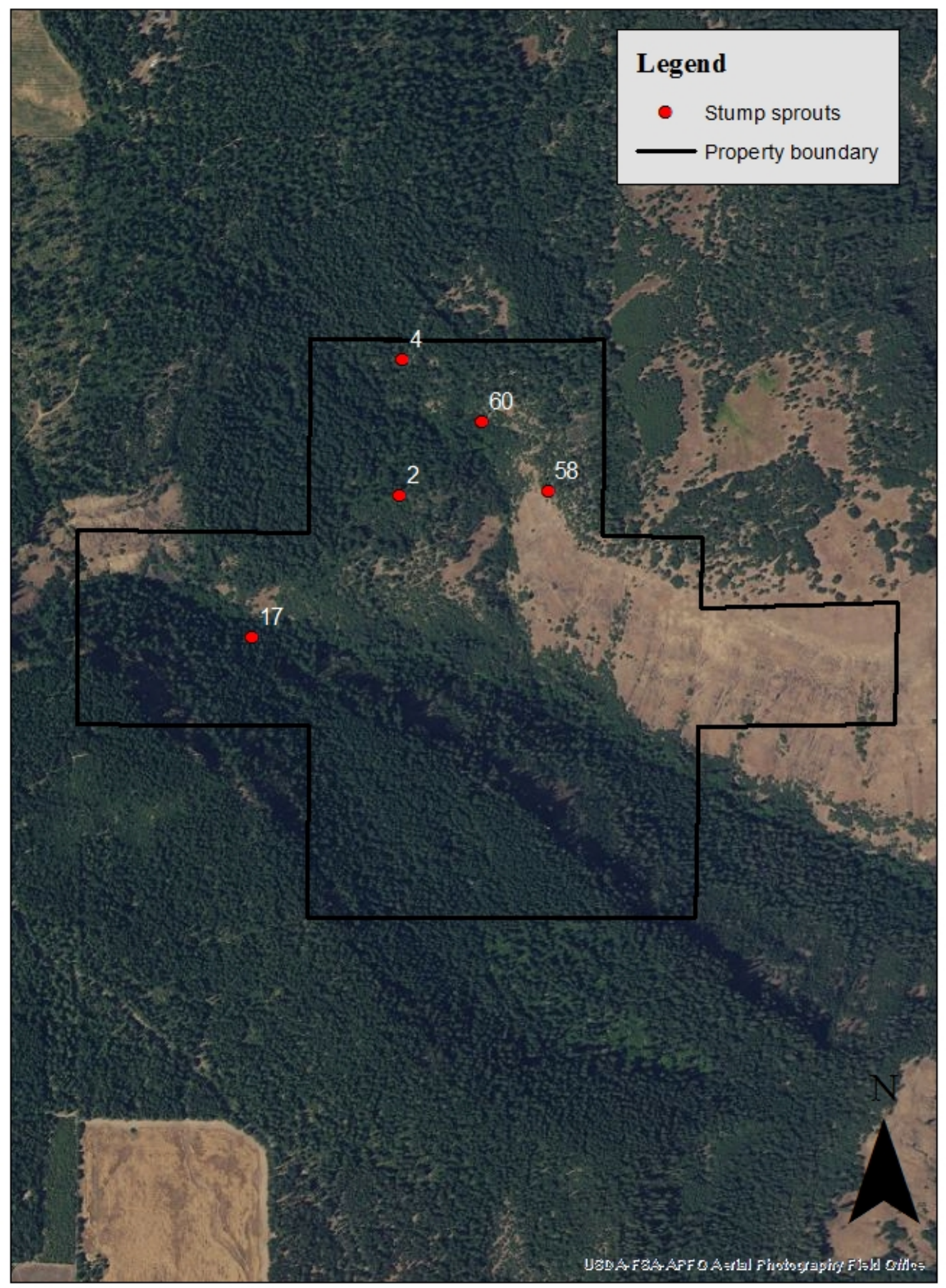

$0 \quad 0.0750 .15$

0.3

0.45

0.6 Miles 
Stand Surface Fuels

\begin{tabular}{|r|r|r|r|r|r|r|r|}
\hline Stand \# & 1-Hour & 10-Hour & 100-Hour & 1000-Hour & Total & $\begin{array}{c}\text { Av. Fuel } \\
\text { Depth }\end{array}$ & $\begin{array}{c}\text { Av. Duff } \\
\text { Depth }\end{array}$ \\
\hline 1 & 0.192 & 0.079 & 0.035 & 2.118 & 2.424 & 8.70 & 3.30 \\
\hline 2 & 0.270 & 0.901 & 0.279 & 2.242 & 3.692 & 1.00 & 2.00 \\
\hline 4 & 0.090 & 0.191 & 0.454 & 1.868 & 2.603 & 7.00 & 0.90 \\
\hline 7 & 0.164 & 0.383 & 0.873 & 3.795 & 5.215 & 3.60 & 1.70 \\
\hline 10 & 0.001 & 0.000 & 0.070 & 0.485 & 0.556 & 10.50 & 1.30 \\
\hline
\end{tabular}




\section{B. Dillacort Creek Property Information}

This section includes three property maps and fuel information by stand to assist with management planning. The Stand Structure Map displays plot locations based on species dominance within stand structure, as well as locations with missing 2017 data. The Douglas-fir Seedling and Sapling Map displays plot locations with high counts of Douglas-fir seedling and sapling counts. Lastly, the Stump Sprout Map displays the plot locations measured for stump sprouts with observed sprouting. 


\section{Stand Structure Map}

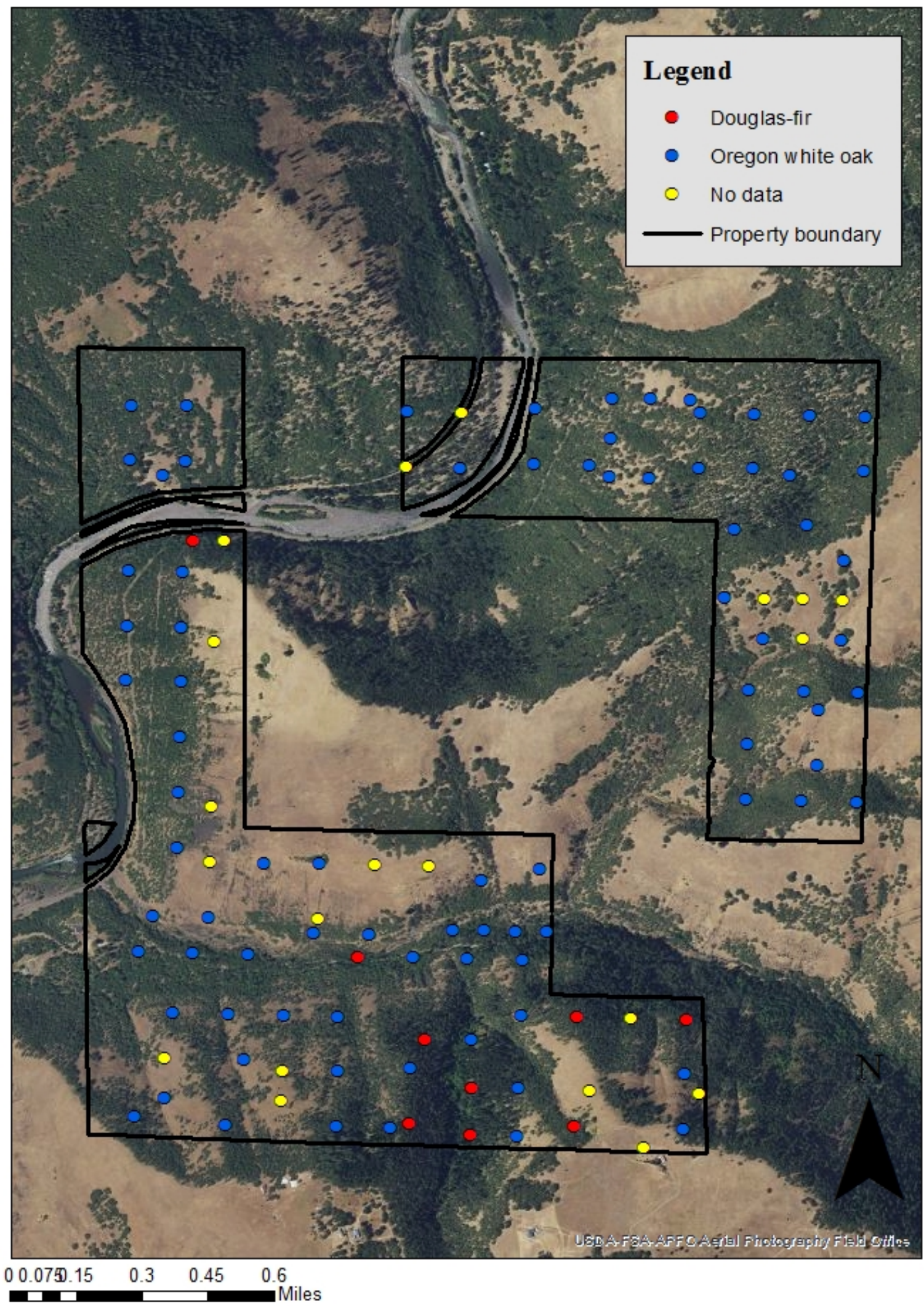




\section{Douglas-fir Seedlings and Saplings Map}

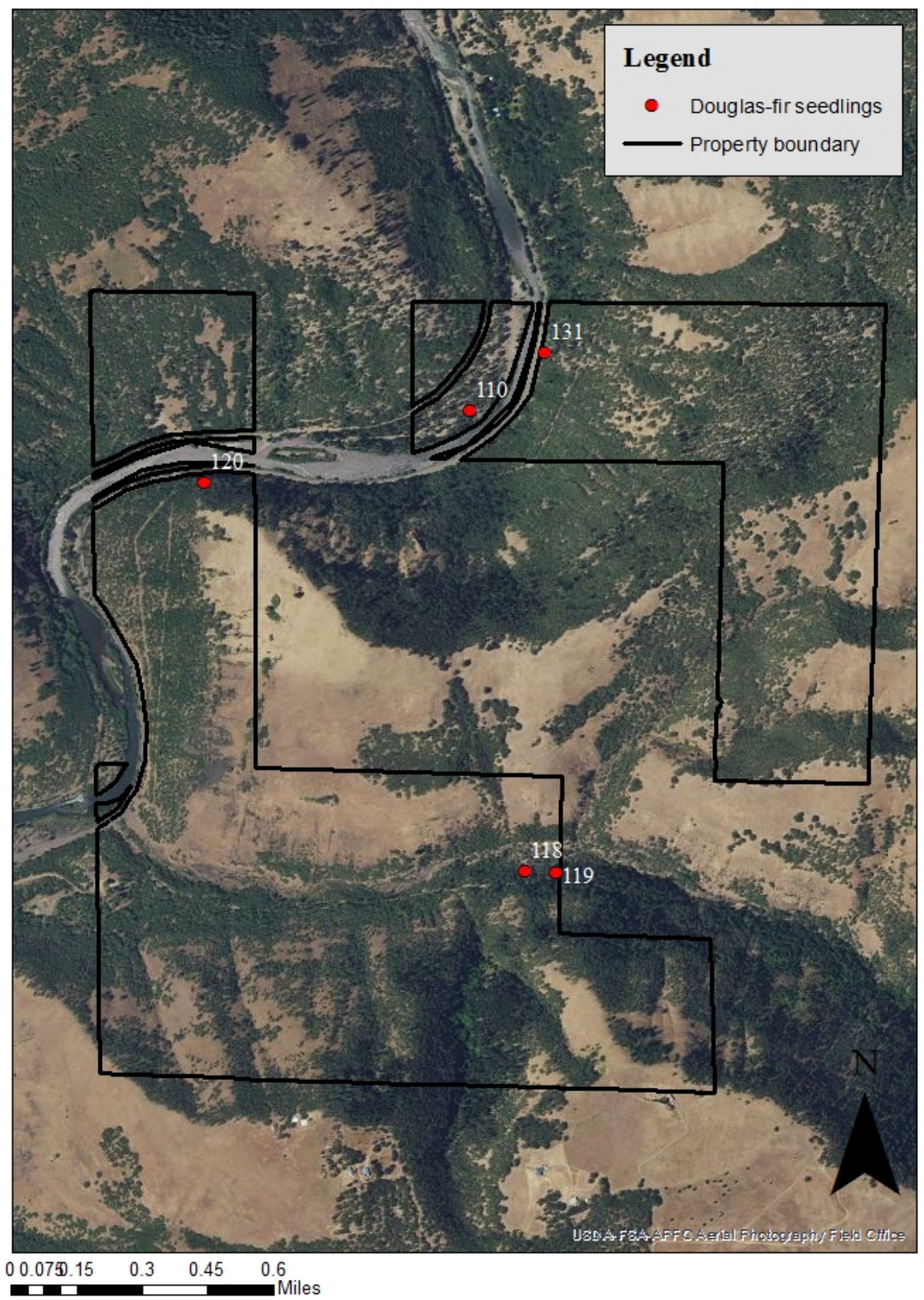




\section{Stump Sprout Map}

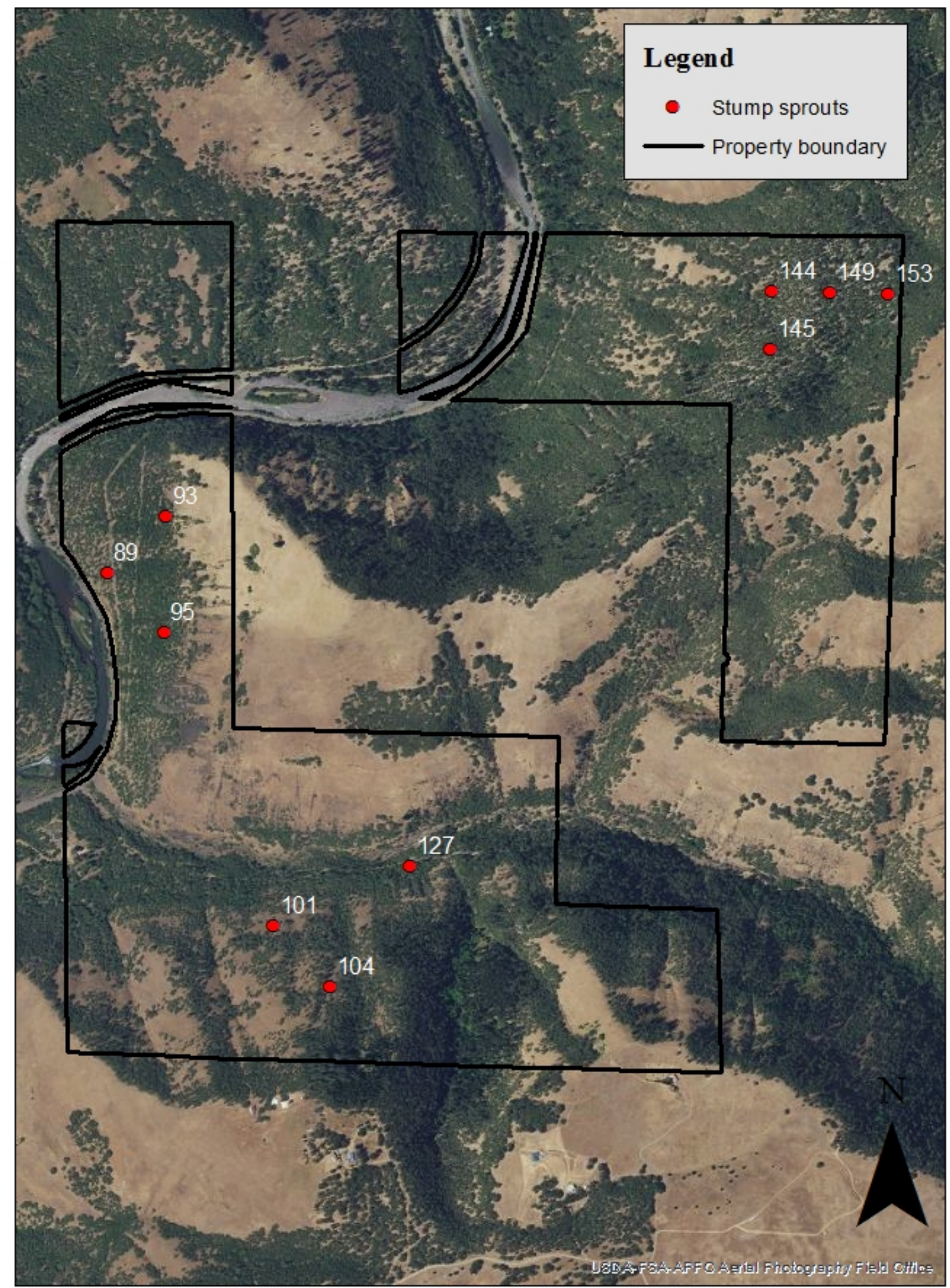


Stand Surface Fuels

\begin{tabular}{|r|r|r|r|r|r|r|r|}
\hline Stand \# & 1-Hour & 10-Hour & $\mathbf{1 0 0 - H o u r}$ & $\mathbf{1 0 0 0}$-Hour & Total & $\begin{array}{c}\text { Av. Fuel } \\
\text { Depth }\end{array}$ & $\begin{array}{c}\text { Av. Duff } \\
\text { Depth }\end{array}$ \\
\hline 1 & 0.011 & 0.000 & 0.593 & 2.003 & 2.608 & 9.30 & 2.60 \\
\hline 2 & 0.000 & 0.000 & 0.000 & 0.123 & 0.123 & 0.00 & 0.00 \\
\hline 3 & 0.029 & 0.023 & 0.140 & 0.304 & 0.496 & 13.40 & 0.60 \\
\hline 4 & 0.028 & 0.158 & 0.489 & 3.695 & 4.370 & 10.60 & 0.90 \\
\hline 5 & 0.000 & 0.000 & 0.140 & 0.353 & 0.493 & 9.90 & 0.20 \\
\hline 8 & 0.012 & 0.023 & 0.105 & 0.549 & 0.689 & 16.80 & 1.00 \\
\hline 10 & 0.002 & 0.000 & 0.000 & 0.019 & 0.021 & 4.50 & 0.20 \\
\hline 12 & 0.000 & 0.000 & 0.000 & 0.000 & 0.000 & 0.00 & 0.00 \\
\hline 15 & 0.005 & 0.000 & 0.000 & 0.957 & 0.962 & 6.30 & 0.00 \\
\hline 18 & 0.000 & 0.000 & 0.000 & 0.019 & 0.019 & 0.00 & 0.00 \\
\hline 20 & 0.000 & 0.000 & 0.000 & 0.141 & 0.141 & 0.00 & 0.00 \\
\hline 22 & 0.016 & 0.045 & 0.105 & 0.166 & 0.332 & 16.50 & 1.10 \\
\hline 23 & 0.036 & 0.079 & 1.047 & 1.162 & 2.324 & 20.30 & 1.80 \\
\hline 24 & 0.004 & 0.023 & 0.035 & 0.184 & 0.246 & 30.00 & 1.80 \\
\hline 25 & 0.000 & 0.000 & 0.000 & 0.000 & 0.000 & 18.00 & 0.30 \\
\hline 27 & 0.031 & 0.056 & 0.558 & 3.316 & 3.961 & 18.70 & 1.60 \\
\hline & & & & & & & \\
\hline
\end{tabular}

